\title{
Fishers' responses to the Danish seiner ban and the history of fisheries governance on the Java north coast
}

\author{
Pujo Semedi $^{1} \cdot$ Katharina Schneider ${ }^{2}$ (i) \\ Received: 3 August 2020 / Accepted: 27 October 2020 / Published online: 1 December 2020 \\ (C) The Author(s) 2020
}

\begin{abstract}
In 2015, the Indonesian government announced that it would prohibit the operation of the so-called cantrang (Danish Seine). The stated purpose of the cantrang ban was to make marine fisheries more environmentally sustainable. In response, cantrang fishers along the north coast of Java staged mass protests, and after 3 years of negotiations and uncertainty, the government exempted the cantrang fleets on the Java north coast from the policy. This paper analyses fishers' responses to the ban from a historical and ethnographic perspective. Specifically, it compares the cantrang ban to two earlier government interventions in the fisheries on the Java north coast, one in 1905, the second 1980/81. With each intervention, a new governance principle was introduced to small-scale fisheries, established elites transferred their capital elsewhere, and new elites emerged who supported the new principle locally. Since 2015, however, only very few members of the established elites have exited the cantrang fishery, and no members of a new local elite have emerged yet who would support sustainability as a governance principle for fisheries. The paper aims to clarify why this was the case. More generally, it suggests that understanding the history of fisheries governance on the Java north coast requires attention to the role of local elites, and therefore to social differentiations among fishers.
\end{abstract}

Keywords Fisheries governance $\cdot$ Cantrang $\cdot$ Indonesia $\cdot$ Historical ethnography

\section{Introduction}

Paul Durrenberger (1988: 211) famously observed that "fishermen fish for a living. They do not make a living by going to meetings". In early 2015, Indonesian fishermen on the Java north coast not only attended, but also organized meetings and demonstrations against a new government policy that they perceived to threaten their livelihood as fishers. On January 9, 2015, the Indonesian government had announced the prohibition of trawl and seine nets in Indonesian waters, on the

Pujo Semedi

pujosemedi@ugm.ac.id

$\triangle$ Katharina Schneider

katharina.schneider@uni-hamburg.de

1 Gadjah Mada University, Yogyakarta, Indonesia

2 Universität Hamburg, Hamburg, Germany grounds that those gear types were not environmentally friendly. The main target of the prohibition was the rapidly growing fleet of cantrang boats (Danish seiners) ${ }^{1}$ that were operating out of six ports on the Java north coast. Cantrang boats were relatively inexpensive, productive and profitable for their owners, and thus their numbers and size had grown significantly since the early 2000s. However, this growth was largely undocumented. Moreover, cantrang boats often violated zoning regulations, and there were indications that they were progressively overfishing the demersal stocks of the

\footnotetext{
${ }^{1}$ Cantrang is a seine shaped into a sack, with a pair of wings on its sides. Each wing is connected with a pulling rope of 300 up to $600 \mathrm{~m}$. The size of cantrang seine itself is small. Its wings are $8 \mathrm{~m}$ long, the seine is $30 \mathrm{~m}$ long, and the sack six meters long (Bayyinah et al. 2014: 222). The cantrang is cast onto the seafloor and laid out in a semi-circle. Afterwards, the ropes are slowly pulled back to the boat with mechanized pulleys, while the boat is travelling slowly (Hakim and Nurhasanah 2016: 219). On average it takes between 60 and $75 \mathrm{~min}$ for a seine casting - setting, pulling, hauling and catch unloadingand on a fishing day usually a cantrang boat makes 10 casting. Cantrang is an active seine with high intensity of casting that in effect makes it very effective in capturing catch.
} 
Java Sea. Since zoning and other regulatory attempts had failed, the Ministry of Marine Affairs and Fisheries opted to prohibit the use of the cantrang and several related gear types altogether. The fishermen protested, and after 3 years of negotiation and uncertainty, the ports of northern Java were granted an exemption from the ban for an indefinite period of time.

In this paper, we review fishers' responses to the cantrang ban, and we try to explain their firm rejection of it and the government's eventual retreat in light of two previous government interventions in the fisheries on the Java north coast. We approach each of these interventions as a change in governance principles in fisheries (see. esp. Kooiman 2003, 2005; see also Kooiman et al. 2005). These principles derived from diverse sources (Bavinck and Chuenpagdee 2005), not all of them within the fisheries sector (Semedi 1991), ${ }^{2}$ and they took shape in the context of broader changes in economic policies in Indonesia (e.g. Hainsworth 1985). As Song et al. (2013) have pointed out, changing governance principles in fisheries is not a simple task. ${ }^{3}$ On the Java north coast, powerful, centralized governments in colonial and post-colonial times nevertheless successfully implemented such changes twice, and a less powerful and centralized government attempted a third change in $2015 .{ }^{4}$ The first change was the introduction of fishers' organisations in 1905, the second, the trawler ban of 1980/81.

In each of these moments, the government re-organized the fisheries on the Java north coast around a new central governance principle. In 1905, this principle was state protection for fishers as small-scale producers. In 1980, it was the extension of market-based economic development to small-scale fisheries, which the trawl ban helped speed up. Most recently, in 2015, the government attempted to make environmental sustainability central to fisheries governance. Every time it introduced a new government principle, the government replaced established local elites associated with the previous governance principle with new ones, who would become the local supporters of the new principles. In the main part of the paper, we review each of the abovementioned three government interventions with a focus on the role and responses of established elites and rising elites. We proceed in chronological order. From this comparison of different moments of intervention, it becomes possible to explain why in 2015, but not in 1905 or 1980, fishers openly resisted the intervention.

\footnotetext{
${ }^{2}$ In the case of agriculture, this was deliberate, as specified by the Presidential Decree No. 40, 1997.

${ }^{3}$ Their paper builds on earlier work in fisheries research that draws on interactive governance theory (Kooiman 2003; Kooiman and Jentoft 2005) and specifies one aspect of fisheries governance that is important to our argument, the role of the so-called "meta-level" governance order, which comprises values, images and principles. See also Chuenpagdee and Jentoft (2018) for an application of their model of fisheries governance to different case studies.

${ }^{4}$ We draw on Tania Li's (2007) analysis of the continuities in developmental governance, which can be extended to the fisheries sector.
}

Our argument is based on the analysis of both historical and ethnographic sources. In our discussion of the earlier two interventions, we have relied primarily on government reports, archives of one national and one regional (Java north coast) newspaper and secondary sources. This data was primarily collected online, through newspaper archives and delpher.nl, the online service of the Dutch National Library. We have also drawn on oral histories and commentaries on these earlier events provided by fishing people at our field sites at Pekalongan and Batang, two neighbouring districts on the north coast of Central Java. The closer our analysis moves to the present, the more we have been able to draw directly on our ethnographic research, which began in 1983 at Pekalongan and in 2013 at Batang. One of the authors has conducted long-term ethnographic fieldwork in Wonokerto, Pekalongan since 1983. He visited the village almost every year until 1990. In 1997-98, he conducted another full year of fieldwork and has since visited Wonokerto at least once every year. The other author has spent about a year in total staying in different households in two villages near the port of Batang, one of the five main home bases of the Javanese cantrang fleet, beginning with 6 months in 2013-14 and continuing with yearly shorter visits since then. In 2018 and 2019, we visited our field sites jointly, which has allowed for a better connection between data from the two research sites. Since 2013, several groups of MA and BA students in anthropology have participated in this research, as well. Five of them have written their theses on specific questions pertaining to the fisheries at Batang and Pekalongan. Moreover, in 2016, we carried out comparative research in two other cantrang ports on the Java north coast and several small-scale fishing ports, for gaining a better understanding of sources of capital in Java north coast fisheries. ${ }^{5}$ The research is ongoing.

The ethnographic data that has been most immediately useful for the argument about the cantrang ban presented in the final part of this paper are family and business histories collected in repeated interviews with 20 owners of cantrang boats at Batang. Between them, they owned 67 boats in 2014, or about a third of the boats active at the time. We also draw on informal conversations and less comprehensive information about the families and businesses of other boat owners. Additional information derives from repeated interviews with two local fisheries officials and less formal conversations with five others. We have also utilized genealogical data and information on village elites gleaned from informal conversations with trusted sources.

While the effects of the cantrang ban are only gradually becoming apparent, it is possible, on the basis of our data, to offer at least a preliminary analysis of fishers' resistance

\footnotetext{
${ }^{5}$ The comparative project covered fifteen ports or landing sites in 4 weeks, with a team of ten student researchers. We thank the Thyssen Foundation for funding this research.
} 
against the cantrang ban, and of the difference between their response to this intervention and the two earlier ones, in 1905 and 1980. One obvious but partial explanation is that fishers utilized new possibilities for open dissent that have emerged since 1998, when Indonesia's New Order government fell (e.g. van Klinken and Berenschot 2014). However, with our analysis of fisheries governance principles and the role of established and rising local elites at different moments in time, we seek to move beyond this reference to changing political conditions, and to suggest how they interacted with fisheriesspecific dynamics. This allows for a more nuanced understanding of the particularities of the cantrang ban, compared to the previous two interventions.

There are three main insights we derive from this analysis. First, an important factor in successfully re-orienting the Java north coast fisheries on a new governance principle in 1905 and 1980/81 appears to have been the exit of established elites associated with the previous governance principles. How and how easily they were dislodged, depended on their social, cultural and political standing, but also on the alternatives that they perceived for their businesses beyond the fishery. The cantrang ban differed from previous interventions insofar as it targeted established elites that, at the time, were members of the majority population and formed an important part of the electorate in certain districts of the political heartland of Java. At the same time, these elites, the owners of cantrang boats, were heavily indebted and could perceive of no easy way of withdrawing from the fishery, short of declaring bankruptcy.

This observation takes us to the second point, the impacts of what one may call the financialization of the cantrang fishery for the mobility of existing elites. By 2015, bank loans had become an important source of capital for boat building and repairs, but also for operating costs and personal expenditures. Beginning in the early 2000s, cantrang owners had become increasingly indebted. Their debt tied them down and rendered them less able to seek out alternative opportunities than had been the case with earlier fishing elites. Correspondingly, they were thus less willing and less able to exit the fishery. Left without exit options, and at the same time enjoying new political liberties that made it possible for them to organize and to voice their dissent, they protested. These protests, however, should be read as an expression of exasperation about the lack of alternatives they perceived for themselves, not as a denial of the need for change in the fishery.

A third point of contrast between the cantrang ban and the previous interventions follows. It concerns the rising elites, who had emerged after previous interventions to become the bearers of the new governance principles. No such new elites have emerged yet since the cantrang ban. Between 2015 and 2019 , the government failed to enlist the support of those cantrang fishers who might have supported the new principle and become members of a new elite. Our ethnographic observations suggest that many boat owners knew that they could only run their boats profitably as long as the government turned a blind eye. Some also knew that the cantrang boats had reached certain technological limits for further expansion, independently of the government's intervention. But instead of tailoring the intervention to those fishers' perceptions, needs and desires, the government put forward a rather narrow argument about the lack of environmental friendliness of their gear that alienated fishers, even though it received support from the scientific community (Priyono 2003; Prisantoso 2011; Lelono and Bintoro 2019).

New governance principles take time to gain a foothold, and since the most recent change was announced only a few years ago, our analysis can only be preliminary. In the following sections, we therefore present more than the minimal amount of historical and ethnographic detail needed to support our own, necessarily provisional conclusions. We hope that others will be able to re-deploy this material in the future, much like we have drawn heavily on perceptive early commentaries on the trawler ban (see esp. Bailey 1988, 1997).

\section{The early twentieth century: state protection for primary producers}

The nineteenth century was a time of expansion for fisheries in Southeast Asia. The expansion was stimulated by processes of state making, improved transport and population growth (Butcher 2004: 61-6). However, fishers on the Java north coast did not benefit. ${ }^{6}$ From the 1870 s onwards, their economy went into decline. A governmental report in 1904 mentions boats left in disrepair and fishers seeking employment in other sectors. The poor state of the fishery was attributed to outside competition, specifically, to the fishers' failure to compete with imported salted fish from Siam (ten Hage 1910: 102). The solution proposed in the report was governmental protection. Among other things, it suggested training fishers to dry and salt the fish; freeing fishers from debt relations with specifically a cartel of Chinese traders who dominated the fish market; providing wood for boat building, credit and salt at a fixed price through a system of government-run depots, and setting up fish market places in designated fishing villages, where fish trading should proceed according to the model of Dutch fish auctions, open for everyone and supervised by local government. The costs for all these measures would be considerable, especially because abuse would not be

\footnotetext{
${ }^{6}$ According to one estimate, there were about 35.000 people out of 4.5 million making a living from the sea on the island of Java in 1820, most of them on the north coast, especially the eastern parts, and around the eastern tip of the island (Boomgaard 1989:117). For the area of Kendal, Semarang and Demak, just east of Batang and Pekalongan, fishing was estimated to provide the main source of income to about 5000 families in 1824 (Masyhuri 1996:78. White 1973: 220).
} 
entirely preventable, but Java would become self-sufficient with regard to fish (Directeur van Onderwijs 1904).

In the 1910s, the government established a total of 14 fishers' organisations in different locations along the Java north coast that would provide capital to fishers, allowing them to bypass Chinese moneylenders. They provided credit to fishers, backed up by soft loans from the government bank. Each association was also meant to set up and manage an open auction for the sale of the catch (Besseling 1913). Auction fees to be paid by fishers and traders were to provide further capital for the organisation. This intervention was a part of a nationwide campaign to improve economic life and people welfare in rural Indonesia, as exemplified by the establishment of village banks and village barns in agricultural villages all over the country (Blink 1926: 97). The campaign was guided by the core value of "civilizing" the inhabitants of the colonies and the principles of paternalism and protectionism that were associated with the Dutch colonial government's "ethical policy" in Indonesia. According to those principles, the government should tightly regulate and supervise primary industries, from the provision of inputs all the way to the fish marketing and processing, in order to protect fishers from free market competition (Furnivall 2010: 302). They were to be protected against the impact of Western capitalism, while the industrial sector was to be developed in a capitalist manner (Boeke 1936: 55; see also Wertheim and Giap 1962:223).

\section{The established elites}

The established elites against whom some of these measures were explicitly directed were Chinese moneylenders who financed boats and provided loans to fishers, sometimes at very high interest rates. They had established themselves in this role since the early nineteenth century. At that time, fishers on the Java north coast fished in small outrigger boats with sails (perahu jukung) close to the shore, using a variety of traps and nets. ${ }^{7}$ They also used larger and more expensive vessels (perahu mayang) that sailed further out to sea to bring in scads that were dried, salted and traded (Butcher 2004:50). The capital for those larger boats was provided by entrepreneurs who were active in the area, and whose main source of income were monopolies on collecting taxes that local rulers rented out (Masyhuri 1996: 79, see also Sutherland 1979). By the second half of the nineteenth century, the majority of tax farmers on the Java north coast were Chinese, who had the necessary capital for successfully competing in the auctions in which the monopolies were traded (Masyhuri 1996:93). Especially those who held

\footnotetext{
${ }^{7}$ Butcher (2004:41) cites a report from 1882 that describes about 40 types of fishing gear used in the waters around Java and Madura.
}

monopolies for selling salt to fishers were in a suitable position to establish themselves as moneylenders and local patrons.

Over time, tax farming arrangements became more centralized and formalized as the colonial state gained in managerial capacity (Butcher and Dick 1993; Butcher 2004: 93). Masyhuri (1996:89-93) describes how in the same period, between the early and the mid nineteenth century, mutually beneficial relations between tax farmers and their agents on the one hand and fishers on the other became increasingly commercialized. Tax farmers vied to accumulate monopolies, and one way of generating the necessary capital was to exploit fishers. ${ }^{8}$ In 1863 , tax farming was abolished and replaced with a more efficient system of raising taxes. Nevertheless, Chinese entrepreneurs remained active in the area, under conditions that were less profitable for them overall. They appear to have utilized yet more exploitative practices as their own conditions progressively worsened. Fernando (2010): 431, see also Kahin 1946) has documented a correlation between the removal of monopolies and farmers' indebtedness to fishers in the late nineteenth century, with another peak in both after 1904, when the last remaining monopolies were removed. A similar trend occurred in the Java north coast fisheries, though the exact mechanisms remain debated. In the early 1870 s, catches along the Java north coast went into decline. Masyhuri (1996:141-57) has interpreted this as a result of a lack of capital under the tax system introduced in 1963, while Semedi (2005:5) has argued that it was the other way around, and that declining fish stocks caused capital flight in the first place (see also de Waart 1924: 61). In either case, by the early twentieth century, productivity in the Java north coast fisheries was low and relations between small-scale fishers and Chinese moneylenders had become a matter of concern to the government.

The 1904 report mentioned above proposed a new system under which the state itself would make capital and other means of support available to small-scale fishers, and in which there would be no role any more for Chinese moneylenders. Indeed, Chinese entrepreneurs withdrew from this role around the time the new organisations were set up. Poortman wrote in De Visscherij (1930: 232) that the fishers' organisations had "redeemed the fishermen from the clutches of the Chinese Kongsies (trading companies)". "

\footnotetext{
${ }^{8}$ They invested in boats and demanded half the catch in return. Not all boats were "tied" to tax farmers in this way (Masyhuri 1996:105-109), but overall, the system of "tying" boats appears to have predominated.

${ }^{9}$ Chinese entrepreneurs retained an important role in fish trading. A detailed history of the history and the continuing involvement of Chinese trading companies in the trade of salted fish from the coast to the hinterland that continues into the present remains to be written.
} 


\section{The rising elites: leaders of fishers' organisations}

As the governance principles of protection and paternalism were implemented in the form of fisheries organisations in different locations along the Java north coast, a new elite emerged that made those principles its own and promoted them at the local level. Its members were the local managers of the fishers' organisations. ${ }^{10}$ Typically, those were prominent figures in the village who had an economic base that permitted them to spend time and energy on the running of the organisation. These local elites oriented their behaviour on that of the colonial bureaucratic class, the priyayi (Sutherland 1979). In Batang, for instance, the fishers' organisation with the name Ngupaya Mina, which specialized in fish processing, was set up at the village of Karang Asem, where relatively well-to-do families of landowners, boat builders and possibly fish traders lived. The people who ran Ngupaya Mina at Karang Asem appear to have had family connections to the heads of other organisations, specifically, to Haji Ibrahim, a rich landowner and prominent figure in another fishing center in the district, Wonokerto.

Thus, the fishers' organisations were in the hands of relatively well to do, land-owning coastal elites, not small-scale fishers. In Batang, the former lived in the village of Karang Asem, the latter, in the adjacent village of Klidang Lor. The latter were newcomers to the coast, former farmers who had fled poverty and unrest in the interior of Java and had taken up fishing as an occupation of last resort. Those who owned boats could apply for membership in Ngupaya Mina; the simple deck hands among them were entirely excluded. Thus, although organisations such Ngupaya Mina were called fishers' organisations, their membership was exclusively reserved for boat owners and fish traders (Besseling 1913:9).

Ngupaya Mina and other fishing organisations took over the economic role of Chinese traders in providing access to capital for small-scale boat owners. They did so by delivering loans from the government's "People's Bank" to fishers for boat building, fish processing and fish trading. ${ }^{11}$ Another part of their income came from running a local fish auction. ${ }^{12}$ Data from

\footnotetext{
${ }^{10}$ The associations' administrators were government officials, but the day-today management of the organisation was placed in the hands of people from fishing villages. For Tegal, we know of one European and one Javanese administrator and five local people who shared the job (Besseling 1913: 9). For Wonokerto, the administrators were two native government officials, and the day-to-day management was in the hands of nine local aides (De Locomotief 24/05/1933).

${ }^{11}$ In Wonokerto, a fishing village roughly the same size as Karang Asem some $20 \mathrm{~km}$ away, the fishing organization earned a loan commission around $f 7.000$ per annum in the early 1930 (De Locomotief 24/05/1933). By comparison, the average catch per fisher was somewhere between $f 43$ and $f 49$ per annum (Semedi 2003:71) .

${ }^{12}$ In the late 1930s the annual report of Pekalongan Residency mentioned that in the first quarter of 1936, Ngupaya Mina sold 121 tons of fish; the number increased to 799 ton for the first half of 1938 and further to 1.396 tons in the first half of 1939. Due to an economic recession, the income of the auction did not rise as sharply (De Locomotief 19/06/1936; Algemeen Handelsblad voor Nederlandsch-Indië 23/08/1939).
}

Wonokerto, for instance, indicates that the fishing association earned around $25-30 \%$ of revenue from the fish auction turnover (De Locomotief 24/05/1933). However, the supposedly open and fair fish auction was compromised by the presence of big fish traders who often were kin or close acquaintances of the organisations' managers. These big fish traders, locally known as jedhot, kept competition out and fish prices low by preventing traders from other places to enter the auction. The fishers tried to make the best out of this situation, by selling part of their catch "illegally" to traders outside the fish auction, relying on the kinds of arrangements that they had had before with the Chinese traders. This allowed fishers to utilize two sources of credit in parallel, the state-sponsored ones through the fishing organisation and informal ones through local traders. This suggests that fishers and elites alike drew freely on both new opportunities and older arrangements, on state paternalism and previously dominant forms of patronage. Drawing on both, they moulded the fishers' organisations according to their own interests.

Local elites benefitted financially and in other ways from becoming leaders of the new organisations. A closer observation of the organisations at Tegal and Pemalang revealed that revenues from the auction revenues were spent mostly for salaries and loans of the association managers and staff (Het Nieuws van den dag voor Nederlandsch-Indië 28/10/1925). Moreover, oral histories from the fishing villages suggest that their role in the organisation allowed the new elites to become providers of social and cultural patronage. Like true priyayi, the organisations' local leaders and their kin gained local prestige, opportunities to expand their social contacts and capital by facing both ways, to the state and to their local clients (e.g. Sutherland 1973). A small number of men faced the state, as official agents of the fishers' organisation that belonged to the state. They used their official positions for establishing contacts and mutually beneficial relations with each other and with state officials at other administrative levels. At the same time, they faced the other way, too, as local versions of colonial bureaucrats who distributed state funding through personalized relations of patronage. They collectively limited access to the auction according to their joint best interests, they organized shadow plays and financed rituals and social events, and fishers could turn to them for emergency funds in times of need. They created informal, highly responsive personalized relations of dependence inside the new governance mechanism of fisheries organisations that were meant to bring fishers under the direct protection of the state.

This pattern of mediated state paternalism, implemented in the fishing villages by local elites, continued after independence, with minor modifications. In the 1950s, the Indonesian government turned the fishers' organisations into cooperatives, according to a pattern familiar from other sectors. Cooperatives were widely regarded as the correct way of implementing Article 33 of the 1945 Constitution, which stated that "economic affairs are to be organised as a joint effort 
based on family principles". ${ }^{13}$ In principle, the fishing cooperatives on the Java north coast would serve the interests of the entire membership, boat owning and non-boat owning fishers and small fish traders alike. However, in Batang, not much appears to have changed when the fishers' organisation Ngupaya Mina became the cooperative Ngupaya Mina. In 1960, Jajuri, a member of one of the elite families of Karang Asem, assumed the leadership of the cooperative. Drawing on contacts and connections afforded by his official role, he cooperated with researchers and fisheries officers in Semarang and Jakarta. He is widely credited with having introduced purse seining to the Java north coast in 1968 (e.g. Butcher 2004: 213; Potier and Sadhotomo 1995: 47). He himself owned as many as 52 purse seiners.

\section{The decline of the cooperatives and the creation of a large-scale fishing sector}

As the Sukarno-Hatta government was replaced by Suharto's New Order government, the latter increasingly used the cooperatives as a local arm of the state. At Batang, the cooperative's right to run the fish auction was withdrawn and was transferred to a new body, Pusat Koperasi Desa (Puskud, Center of Village Cooperative), lodged at the provincial level of the government. The head of the cooperative became a retired member of the armed forces, and the local elites withdrew. Haji Jajuri's children moved out of the village and took up occupations outside the fishery. Haji Jajuri himself and other members of Karang Asem's elite remained involved in the fishery but pursued other avenues that were opened up by changes in the sector, and that we briefly summarize below.

By the late 1960s, the dominant argument in Indonesian economics was that the country's natural resources were under-utilized. According to government estimates at the time, the potential yield of Indonesian fisheries was 5.5 million tons, while in 1969 , only 785.000 tons of fish were harvested. This was attributed to the lack of capital and technological limitations of the fishing fleet (Kompas 26/ 06/1969). The solution proposed was to open the sector up to foreign capital investment (e.g. Krisnandhi 1969). The mechanisation of Indonesian fisheries had already begun in the 1950s, with the support of the US international development agency and the Japanese war repatriation fund, but the program provided just a few hundred motorized fishing boats and thus had a limited effect (Semedi 2005: 9). By the 1960 s, Indonesian fisheries officials took inspiration from the economic success of trawling in the rapidly modernizing Japanese fishing fleet. Following explicit encouragement

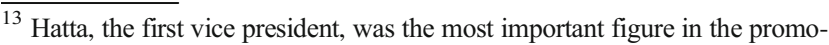
tion of cooperatives (Hatta 1957; Higgins 1958).
}

from the government in 1967 (GoI, Law No. 1/1967), eight foreign companies, mainly Japanese, began trawling in Indonesian waters. In collaboration with business entities owned by the Indonesian military, they operated a fleet of 112 boats in total. A year later, tax and other incentives were provided for domestic investment, and domestic companies joined with 74 trawler boats (GoI, Law No. 6/1968; Kompas 03/01/1983).

Thence emerged the "dual structure" of the Indonesian fishery, with an industrial sector complementing the old small-scale fisheries (Bailey 1988). The trawler fleet was supposed to "exploit the fisheries resources beyond the reach of the small-scale fishers and at the same time to act as a stimulus for the development of the small-scale fisheries, particularly in the marketing of their catch" (Bailey and Dwiponggo 1987:67). ${ }^{14}$ Trawling was thus meant to complement the weakness of the country's primarily small-scale (below 5GT), low-technology, labour intensive fisheries. In fisheries as in other sectors in the late 1960s, "choices favoring efficiency over equity, exports over domestic market and resource exploitation over resource management" led to the creation of a "dualistic industry structure" of modern, large-scale, commercial fishery and traditional, small-scale, subsistence oriented fishery (Bailey 1988:3).

Labour for the emergent trawler fishery came from the small-scale fishing sector. Compared to the incomes of small-scale fishers, those of trawler crew members were extremely high and stable across the seasons, and the work was physically less taxing than on the non-motorised small-scale boats. ${ }^{15}$ The trawler fishery also provided opportunities for small-scale business and informal employment in fish trading, processing and auxiliary industries around the fishing ports. The shrimp catch itself did not provide any opportunities for petty trading, because it was bought directly by export companies based in Semarang. But the bycatch, demersal fish, became the main source of raw material for the local production of dried fish that was traded along the pre-existing trade chains to the hinterland. ${ }^{16}$ In Batang, for instance, Grandma Rasinah, the wife of a small-scale fisherman at Seturi hamlet, took advantage of the abundant supply of demersal fish in the 1970s to open a small fish processing business that became a lucrative source of revenue for her household and allowed her to buy a small fishing boat.

\footnotetext{
${ }^{14}$ The potential of demersal fisheries in the Java Sea was assessed by an international team of researchers and on the basis of a field survey conducted between 1974 and 1976 (Pauly et al. 1996).

${ }^{15}$ The monthly income of crew members on the trawlers was about twenty times as high as that of small-scale payang and cantrang fishers (Bailey and Marahudin 1987: 108; 121; see also Kompas 24/09/1980).

${ }^{16}$ The volume of salted fish trading increased as the trawler fishery developed (Kompas 05/01/1980; 10/10/1980).
} 


\section{Intermediate trawling: a new arena for the established small-scale fishing elite}

Elites in fishing communities and non-fisheries-related local entrepreneurs responded rapidly to the opportunities they perceived in trawling and effectively complicated this dualistic structure by developing what one might call a "medium-scale" trawl. The trend started in Bagan Siapi-api on the east coast of Sumatra, where Chinese entrepreneurs learned the productivity of Malaysian trawl on the other side of the Malacca Strait. From there, trawling spread to Java. Here, Indonesian Chinese and a few Javanese entrepreneurs in coastal districts, Batang and Pekalongan included, invested in trawl boats with a gross tonnage of up to 30GT. These boats were cheaper and less productive than the large-scale trawlers, but they were much more expensive and productive than the small boats of smallscale fishers. This medium-sized trawling fleet grew rapidly. In 1975, the number of trawlers in Indonesia reached 2.202 according to official statistics. The shrimp catches from Indonesian waters rose to 33.801 tons with a total export value of US\$199.2 million in 1979 (Bailey and Dwiponggo 1987:85).

In Batang, the emergence of trawling was accompanied by a shift in the role of local elites from leaders of governmentsupported cooperatives to investor-owners relatively unattached to local government. This shift came about gradually in the 1970s when the New Order government transformed fishing cooperatives into a political machine to mobilize support for the ruling party, Golkar, by installing government or military personnel as leaders of the cooperatives. Moreover, in 1978, the local cooperatives lost control over the income from the auction, ${ }^{17}$ and thus their main source of income. As a consequence, local elites lost their interest in serving on the management of the cooperatives. In the commercial trawling sector, they found sources of credit and trade chains that were largely independent from direct government intervention. Moreover, they promised to be more lucrative. An example of a member of the local elite responding in this way is Haji Ragum from Wonokerto. He was a rich boat owner, as well as a manager of the fishing cooperative up until the early 1970s. As the fishing port of Pekalongan developed in the early 1970s, he moved his fleet and his house to Pekalongan, where his fleet developed to dozens of purse seiners and several trawlers. Another example is Haji Jajuri from Batang, already mentioned above.

However, the rapid spread of trawling along the coasts of Java and Sumatra generated serious conflicts. The trawlers

\footnotetext{
${ }^{17}$ In 1978, the control of the auction was lodged with the district (kabupaten) government as one of their sources of revenue. In 1984, it was shifted to the PUSKUD, the central organ for the village cooperatives that was tasked with the management of tax income from the auctions (Daryanto 2011). This indicates that previously, the transfer of revenue from the fish market to the district government by the local fishing cooperative had not run well.
}

competed directly with small-scale fishers for catch and fishing grounds in the shallow coastal waters. These waters were the most fertile fishing grounds for the shrimps that the trawlers targeted, but they were also the only grounds within reach of small-scale fishers, whose catches were reduced drastically as a result of trawling. Small-scale fishers resisted by attacking and burning stores and houses of trawler owners on land and trawl boats at sea. Some incidents led to human casualties. ${ }^{18}$ The government tried to resolve the problem with a zoning system that prohibited trawlers near the shore (Kompas 18/10/1979), but this proved difficult to enforce and the conflict continued. Alarmed by the conflict and difficulties suffered by small-scale fishers, Himpunan Nelayan Seluruh Indonesia (HNSI), the fishers' functional group in the New Order system, advised a ban on trawling at its national meeting in April 1979, on the grounds that trawlers "cause great harm to small fishers and national development" (Kompas 05/04/1980). President Suharto adopted their proposal (Kompas16/05/1980). On July 1, 1980, he issued a Presidential Decree that prohibited trawling in the waters off Java, Bali and Sumatra and reduced the number of trawlers in other areas to 1000 .

\section{The 1980/81 trawler ban and Its effects on large-scale fisheries: hidden continuities}

The trawler ban of 1980/81 is perhaps the most momentous, most widely known government intervention in fisheries in Indonesia to date. Our analysis below builds on Bailey's $(1988$; 1997) earlier ones and extends them forward in time. Bailey was interested in the interrelation of fishers, the state and foreign donors, and he pointed out the continuities, despite appearances to the contrary, of the government's interest in developing the large-scale fishing sector with an eye to maximising export revenues and involving foreign capital. With the benefit of forty year's distance to the events, we can confirm and extend many of his early observations.

Bailey (1988: 38) appreciated the government's decision to ban trawling as a dramatic action, "sufficiently rare to be remarkable". It was backed by a growing concern among researchers and managers over the plight of small-scale fishers that were adopted by savvy politicians. The latter revived ethnic stereotypes and portrayed the trawler owners as Chinese (as many of them were) who invaded Javanese small-scale fishers' fishing grounds. Bailey argued that the ban resulted, in the final instance, not from scientists' or political interests, but from small-scale fishers' demonstration of

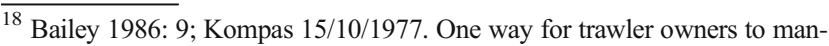
age this threat was to hire security personnel for their boats. It was an open secret at the time that boat owners cooperated with the security personnel in order to protect their business (Purdey 2006: 191).
} 
their willingness to use violence to promote their cause (ibid.: 36). Peace and order were important values of the New Order regime, and the violent clashes in Java's ports pushed the President to take firm action. He put his own weight and that of the military behind a ban, even though it affected the business interests of capital providers for large-scale trawling, many of whom had strong political connections. At the same time, Bailey noted that the priorities of fishing governance under the New Order (growth, productivity and a higher exploitation of a resource that was considered abundant) had not changed. ${ }^{19}$ He suggested that the government merely found a new frontier to exploit. It shifted its investments to shrimp farming, uniquely suited to match the demand of the global market for shrimps and less susceptible to the violence of small-scale fishers who were defending their fishing grounds. Actors in the large-scale fishing sector who had previously owned trawls shifted to purse seining.

Bailey's perception of a continuity rather than a rupture in government priorities for foreign investment and export earnings and his perception of shrimp farming as a new frontier has since proved accurate. Soon after the trawler ban, the total value of shrimp exports increased again, now with the harvest from aquaculture. ${ }^{20}$ Strong market demand had pushed Indonesia to engage in both extension and intensification of shrimp culture. A tremendous increase was achieved, but by 1995 the shrimp industry started to decline due to virus attacks and other environmental problems (Semedi et al. 2003). In addition, as we know now, large-scale trawling remained lively in the Arafura Sea, where highly productive shrimp fishing grounds could be found and fewer small-scale fishers were active than in the Java Sea. ${ }^{21}$ As a precaution against the waste

\footnotetext{
${ }^{19}$ In the late 1960 s, economic policy in Indonesia was dominated by the promarket "Berkeley Mafia", staff at the Faculty of Economics at the University of Indonesia who had obtained their $\mathrm{PhD}$ from Berkeley with support from the Ford Foundation (Irwan 2005; see also Simpson 2009). From the 1970s onward, the government sought to promote equity besides political stability and growth (Hainsworth 1985). Hainsworth noted that multiple interests and goals interacted in the late 1970s, some sector-specific and others cross-sectoral, and that learning processes were highly dynamic and intentions were often temporarily displaced by contingencies. Nevertheless, he argued that "a national ideology of ethos of development can usually be detected" (ibid.: 152). Bailey's observation about a fundamental continuity in the orientation toward economic growth as a key principle of fisheries governance thus fits within a broader, cross-sectoral pattern.

${ }^{20}$ Brackish water ponds in Indonesia grew almost double from 45.809 ha in 1978 to 89.379 in 1988 (BPS 1980, 1990). The increase in the size of fish ponds during that period was accompanied by a shift to a new type of aquaculture. Prior to 1980 almost all Indonesian brackish water ponds were used to cultivate milkfish and tilapia, with natural shrimp as a byproduct. After the 1980 trawler ban, a growing portion of the fish pond was used for shrimp cultivation.

${ }^{21}$ Beyond the Arafura Sea, too, some trawlers remained in operation, under different names and apparently escaping government attention. For instance, in 1984 and 1985 fishers in South Kalimantan reported the activities of a number of trawlers under the protection of the district military apparatus (Kompas 13/ 12/1984). When HNSI-officials and members of the province parliament were asked to comment, they scrambled to point out that acting against trawling fell into the domain of the security apparatus (Kompas 18/05/1985).
}

of natural resources, the trawlers' bycatch was sold cheaply to the state-owned company PT Perikani and was channelled into the market through the Cooperative Mina Siwa Lima, run jointly by the central cooperatives of the army and the navy. Thus, the mutually beneficial cooperation between foreign capital and the Indonesian military continued undisturbed, until stocks of shrimp in the Arafura Sea were depleted. ${ }^{22}$ By 1995, many of the modern trawl boats were rusting along the berth for lack of catch. Of 15 joint-venture businesses that held licences for fishing in the Arafura Sea, only six remained in operation (McLeod 1997: 39). The domestic companies that ran wooden trawl boats in the Arafura Sea, whose operating costs were lower, remained in operation for a few more years before eventually they too closed their business. ${ }^{23}$

On the basis of our ethnographic observations and oral histories collected in fishing villages on the Java north coast, we add the following to Bailey's analysis: Bailey was correct in pointing out that the trawler ban, contrary to all appearances, did not interrupt the government's commitment to commercial fisheries. Quite to the contrary, it extended the commitment to economic growth based on free market principles and applied it to small-scale fisheries, as well, which had so far been deemed in need of protection from the market. Evidence for this process on the Java north coast is provided by Collier et al. (1977), who explicitly note the parallels of development in small-scale fisheries with Green Revolution in the agricultural sector. That small-scale fisheries should be included in market-based development is consistent, moreover, with analyses that have documented the power and far-reaching implications of Indonesia's "accelerated modernisation" (Simpson 2009). Simpson has placed the history of economic

\footnotetext{
$\overline{22}$ There were 14 foreign companies and 26 domestic trawling companies in Arafura Sea (Comitini and Hardjolukito 1983: 8). The decision to keep the Arafura Sea open for trawlers was made to honour the 30 years fishing licenses of the foreign fishing companies, but national companies whose shareholders were high-ranking officials in Jakarta and from the President's family benefitted, too (Tempo 16/04/2000).

${ }^{23}$ PT Bintuni Mina Raya operated a trawl fleet in Arafura Sea. In 1998 the company was struck by financial problems, with a total debt of US \$49 million. Their fishing fleet remained tied along the pier in front of the company's cold storage facility in Wimbrau, Papua, and in 2007 the company was declared bankrupt by the Commercial Court, Jakarta (Bisnis Indonesia 14/04/ 2011). In the late 1990s, the trawler ban came to be questioned openly. In 1996, the Minister for Agriculture issued the decree No. 509/1996 concerning import licences for trawl boats into Indonesia, which were to be granted a fishing license in the Banda Sea. In 2002, the Minister of Marine Affairs and Fisheries Rokhmin Dahuri spoke against the ban, because it put Indonesian fishers at a disadvantage compared to foreign ones. He planned to revoke the ban on trawling in Indonesia, although within certain zones, outside the spawning areas of shrimps, and by small-scale fishers. The provincial government of East Kalimantan similarly called for legalizing trawling again, on the grounds that fishers in neighbouring Malaysia used trawls, too. People received this proposal coldly and it was apparently taken off the table. In 2010, Minister of Marine Affairs and Fisheries Decree No. 6/2010 reiterated that the use of the trawl was not legal in Indonesia, and in 2015, Minister of Marine Affairs and Fisheries Susi Pujiastuti issued the decree No. 2/2015 that confirmed this again.
} 
governance in Indonesia in the context of cold war politics and has documented the role that the interests of American and multinational organisations played in the re-conceptualization of what "development" meant in the late 1960s and 1970s. He has also traced the implications for agriculture and population control. Fisheries were no exception. If the trawler ban did, indeed, form a significant rupture in Indonesian fisheries policy, then this rupture affected primarily small-scale fisheries, not the commercial ones that were ostensibly targeted. Moreover, the trawler ban did not limit the reach of commercial principles, but accelerated its extension to small-scale fisheries. The removal of trawlers from small-scale fishers' fishing grounds was a necessary precondition for easing small-scale fishers' path into the market, not a continuation of the older principle of state protection of small-scale producers from capitalist development. We substantiate this point below, and we show how small-scale fishers have adjusted to the new situation, again by describing the fate of the outgoing and the rising elites. Among the former were Haji Jajuri, Haji Ragum and other trawler owners; among the latter were enterprising people among the small-scale fishers who were willing to become what the government wanted them to become: maritime entrepreneurs in a market-oriented fishery.

\section{Responses to the trawler ban on the Java north coast}

In response to the trawler ban, some ex-trawler owners on the north coast of Java and Sumatra turned to purse seining (Bailey 1988: 36; Potier and Sadhotomo 1995: 58). It was not a smooth exit path. The new purse seiners belonging to ex-trawler owners increased competition for labour in the already existing purse seine fishery. For instance, after the trawler ban, Haji Jajuri' s flourishing fleet of purse seiners had to compete over crew members with the purse seining fleet based in neighbouring Pekalongan. In the early 1970s, the government had developed Pekalongan into a national level fishing port, with a large fish auction hall and better road access to consumer markets in Jakarta and other cities in Java. Moreover, boat owners at Pekalongan were more willing to invest in the development of boats and equipment than Jajuri was or could afford to be. Thus, the fleet at Pekalongan grew,${ }^{24}$ while purse seining in Batang went into decline. Haji Jajuri's children are no longer boat owners. Making use of the education they had enjoyed, they exited the fishery and are now doctors, engineers and university lecturers. However, not only Haji Jajuri's children exited the fishing sector; Haji Ragum's at Pekalongan, too, took up other professions, even

\footnotetext{
${ }^{24}$ From 1986 to 1996 , boat numbers in Pekalongan increased from 337 to 553. Average boat sizes grew from 33 GT to $76 \mathrm{GT}$, and catches, from 67.302 ton to 80.289 ton (Semedi 2003: 140).
}

though his purse seining business developed very well. While the houses of former trawler and purse seiner owners and their families - that is, of those who originally gained their economic capital and cemented their social standing as leaders of fishing associations - are still present in the villages, they are inhabited and maintained by less successful relatives, often old people and perhaps children from the extended family. The economically active and prominent members of those families have their centers of activity elsewhere, usually in towns.

Small-scale fishers did not have the option of exiting the fishery, whether they lost their lucrative employment as trawl crew members or whether they were relieved by the expulsion of trawlers from their fishing grounds. It is worth recalling that members of both groups were found in the same villages and hamlets, often in the same families and households. Those who had suffered losses in catches due to the operation of trawlers had supported the ban; those who lost their employment and incomes had opposed it. During the violent incidents that triggered the trawler ban, their lives were on the line, and after the trawler ban took effect, they had to return to more physically demanding work and lower incomes in local fisheries or elsewhere. Pontius Batubara, a fishery observer at the time, estimated that the trawler ban would threaten the livelihoods of 18.000 crew members (Kompas 27/05/1980; Kompas 31/12/1982; Studyanto 1986). Nevertheless, the government did not differentiate between the winners and the losers of the ban among the small-scale fishers, but treated them all the same: as potential entrepreneurs who, with a little bit of start-up funding, would turn from subsistence fishers into independent, self-responsible market participants.

In the early 1980s, small-scale fishers in Indonesia were given the opportunity to acquire a 5 GT boat with nontrawling gear through a low interest, small investment credit scheme (KIK). ${ }^{25}$ This scheme formed part of the promotion of micro-credit programmes, and of the financialization of village life and economies. KIK-credits were promoted in the fishing villages through the-half dead-local fishing cooperatives. Thus, the measure reached only its members, those who were registered as boat owners (including those who had abandoned their boats to work on trawlers). Among the boat owners, the ones with the closest relations with the managers of the cooperatives stood the best chances of receiving a loan. This accounts for the fact that both in Pekalongan and in Batang, the KIK-recipients were clustered in certain fishing villages and hamlets, while other hamlets were left out (Damayanti 2016).

\footnotetext{
${ }^{25}$ In 1982 some 200 ex-trawler crew members were trained to start small businesses as shrimp farmers. In a meeting with north coast of Java fishers the Secretary of the President stated that the government would provide boat credit for small-scale fishers and ex-trawler crew members to mitigate the negative impact of trawler ban (Kompas 09/08/1980; 09/09/1980a; 09/09/ 1980b; 07/11/1980; 27/03/1982).
} 
However, not all KIK-recipients were able to benefit from the "gift of the trawler ban", as they called it, and to become successful entrepreneurs. First, fishers in areas with welldeveloped infrastructure, such as a port, auction halls and feeder roads, and with ready access to urban fish markets were in a better position to benefit. Where these conditions were not given, for instance in the northern part of Jepara regency, small-scale fishing predominates up until today. Second, for being able to benefit from the funding made available through the KIK-scheme, fishers needed capital of their own. KIKboats tended to come in a poor state of repair. Moreover, they came equipped with gill nets that proved unproductive, at least for fishers in Batang and Pekalongan. After a few months of trial and error, they replaced their gill nets with a trammel nets that provided them with a good income during the shrimp season, from December to February. However, around 1986, shrimp catches became increasingly poor. Those fishers who had saved or could access capital by borrowing from kin started experimenting with various gear types, including longlines and cantrang. Those without capital at their disposal shifted to a small-scale trawl called arad that could be run on a small boat with just one person. They knew that arad fell under the trawler ban, but switching to a legal but more costly fishing gear was beyond their means. The government was aware of this and occasionally conducted operations to confiscate prohibited gear, but because the fishers lacked a viable alternative, this did not resolve the problem. ${ }^{26}$

In the late 1990s, an unprecedented opportunity presented itself to those KIK-recipients who happened to be using bottom long-liners by then. Their incomes rose when the rupiah prices of expensive species for export rose at the time of the Asian financial crisis. This gave the owners of bottom long-liners additional capital to enlarge their businesses. At Batang, they equipped their boats with cantrang nets. ${ }^{27}$ In the 1990 s, cantrang nets were predominantly used as a secondary gear to obtain bait fish for the bottom longlines, although some smaller boats used it as their primary gear. ${ }^{28}$ But by the late 1990 s, owners of larger boats were shifting to the cantrang as a primary gear, encouraged by

\footnotetext{
${ }^{26}$ In 1994, for instance, 58 arad nets were confiscated in Cirebon (Kompas 20/06/1994; 02/01/1996).

${ }^{27}$ Cantrang is a seine shaped into a sack, with a pair of wings on its sides. Each wing is connected with a pulling rope of 300 up to $600 \mathrm{~m}$. The size of cantrang seine itself is small. Its wings are $8 \mathrm{~m}$ long, the seine is $30 \mathrm{~m}$ long, and the sack six meters long (Bayyinah et al. 2014: 222). The cantrang is cast onto the seafloor and laid out in a semi-circle. Afterwards, the ropes are slowly pulled back to the boat with mechanized pulleys, while the boat is travelling slowly (Hakim and Nurhasanah 2016: 219). On average it takes between 60 and 75 min for a seine casting - setting, pulling, hauling and catch unloadingand on a fishing day usually a cantrang boat makes 10 casting. Cantrang is an active seine with high intensity of casting that in effect makes it very effective in capturing catch.

${ }^{28}$ Van Kampen (1923:28) mentions the use of the cantrang on the Java north coast in the beginning of the twentieth century. In the 1960s, the cantrang was operated manually from a sail-powered boat with three crew members (Ernawati et al. 2011: 193). In the 2000s, fishers used a bigger and mechanized version of the old one, which required 15-20 crew members to operate.
}

enterprising fish traders. The cantrang was ideally suited for meeting the demand for both large and small, expensive and cheap demersal fish in expanding urban markets. In conjunction with the growth of these markets, a new fishery emerged, the cantrang fishery (Fauda et al. 2018:78).

\section{The fishing elites of the early twenty-first century: the cantrang owners}

The detailed business histories of 20 boat owners that we collected at Batang indicate a significant growth of the local cantrang fleet since the late 1990s, and especially since the early 2000s. At the turn of the century, those twenty owners owned 15 boats between them; in 2014, the total number of their boats had risen to 67 . Several of these boat owners estimated that the number of boats active in the port in 2013-2014 was around 180-200, while a decade earlier, about 100 boats would have operated out of this port. Furthermore, the cantrang boats grew in size, as becomes apparent from the business history of one of them, whom others regard as a role model. In 1998, after shifting from bottom long-liners, he owned his first cantrang of $25 \mathrm{GT}$, in 2002 he built one of $53 \mathrm{GT}$, in 2005 one $83 \mathrm{GT}$, in 2010 and 2013 one of 100GT each.

Based on boat owners' business histories, it appears that three factors contributed significantly to the growth of the fleet in the 2000s and early 2010s. The first, already mentioned above, was strong demand for their catch and the expansion of markets, especially for the small, cheap demersal species that form about half of their catch in volume (not in value) ${ }^{29}$ In the 1990 s, they were used as bait fish for bottom long-liners. The owners of the first cantrang in the 1990s treated them as bycatch. Local fish traders, however, perceived in them an opportunity for entering the market for "filletan", scraped fish flesh that formed the raw material for fish-balls that were a popular street food in Sumatra, and later for a variety of frozen seafood products sold in supermarkets under such creative names as "crab sausage". In 1997, an enterprising trader set up the first local processing plant for scraping the small fish and sending the flesh to buyers in Sumatra. By 2013, about twelve processing plants were employing between 70 and 250 women from fishing households each, as well as ten to twenty men each who were responsible for packaging the fish and loading the trucks. ${ }^{30}$ By December 2014,

\footnotetext{
${ }^{29}$ In another port, the portion was higher. Captains had some control over the ratio through their selection of fishing grounds. Which ones they chosesandy or grassy ones for the small demersals, spots near corals for larger ones - depended on their assessment of the demand and prices in the port, which in turn depended on the strength of the local fillet processing sector, relative to the buying power of local traders who dealt in large demersals. The accessibility of particular fishing grounds, dependent on their distance from a particular port and the frequency of patrols that prevented fishing near corals, also mattered. Finally, fishing near corals required experience and skills.

${ }^{30}$ We estimate a volume of about 15 tons of processed fish fillet leaving Batang per day.
} 
we counted fourteen processing plants, and many of our acquaintances were hoping to set up their own in the near future.

The second factor that facilitated the growth of the cantrang fleet was the high vertical mobility that it offered fishers, and that retained them in the sector even as educational opportunities increased. Even simple crew members could rise to being a boat owner. Some made this transition within the local fishery, first to the specialist role of engineer and then to that of captain. Successful captains' shares were high enough to allow captains to save up for a boat. More common, however, was another route to ownership, maritime labour migration. Some migration channels date back to the 1980 s, but many emerged more recently, some for women, but most for men. Fishers from cantrang ports were commonly hired on tuna boats based in Bali or Jakarta, but also on Taiwanese or Japanese fleets and on boats travelling under different flags and operating as far away as Panama, West Africa, New Zealand or the Central Pacific. In the 2010s, a vocational school was set up in Batang that actively channelled youth from fishing hamlets into maritime migrant labour. At those schools, their fishing background was an advantage rather than a stigma. From an outsider's perspective, school fees were onerous, administrative fees for their first contract abroad highly exploitative, their pay was poor (300 US\$ a month for a first-time contract), visa problems were common and the work was very hard. But from fishers' perspectives, migration offered not just an occasion to broaden their horizon, but more importantly, they could realistically hope to save enough for building a house, a boat or both after one or two three-year contract periods, usually between the age of 18 and 25.

The third factor contributing to the rapid growth of the cantrang fleet, and arguably the one most important if one wants to understand fishers' responses to the cantrang ban, was the accessibility of bank loans for boat owners. Out of 15 owners at Batang who were active before 2000, only two mentioned that they relied on bank loans for financing their boats during those years. ${ }^{31}$ The others acquired their capital from incomes as crew and captains on the local fleet or on Jakarta-based or foreign fleets, or they borrowed from family and friends. After the 2000s, by contrast, only three out of twenty boat owners claimed that they "did not trust banks". The others had developed their "cooperation" with the bank along with their boats, starting with small loans of about Rp.50 million and gradually working up Rp.600 million per loan in the case of one owner. ${ }^{32}$ Some owners had debts with multiple banks adding up to more than a billion rupiah. Rigid repayment schedules sat uneasily with fluctuating incomes in the fishery, as all of them confirmed. The more boats an owner had in operation, the easier it was to even out losses from one

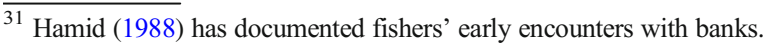

${ }^{32}$ Currency exchange rates have been fluctuating, from between 8.000 and 15.000 rupiah to the US dollar.
}

with profits for the other, and the larger the sums that owners considered safe to borrow.

Beyond fishers' businesses, their entire livelihoods became increasingly dependent on capital acquired from banks. On the one hand, boat owners did not use bank loans exclusively for business investments, but also for buying land and building houses (which, in turn, served as collateral for future loans), for emergencies and sometimes for household consumption. On the other hand, alternative types of financial relations in the fishery that predated fishers' reliance on bank loans became quantitatively less important; were themselves increasingly intertwined with relations with banks, and appear to have become increasingly modelled on bank loans in the way they were conducted. These sources of capital included rotating credit schemes (arisan) within hamlets and professional groups; credit extended by fish traders or equipment stores toward operating costs; individual loans from moneylenders, and the pawning of mobile assets to pawnshops in urban centers. ${ }^{33}$ Reciprocal "contributions" to weddings and other celebrations that yield a profit for the host have become part of fishers' calculations of income, expenditures and capital too. ${ }^{34}$ The spectrum of these arrangements is broad, but in general, interest was negotiable, repayment schedules were adjustable to fluctuating catches, and appeal to creditors on the basis of compassion and social trust were acceptable. Moreover, most arrangements, donors and creditors were both aware of their mutual interdependence. When fishers first took out bank loans, they considered them less important and less binding than such arrangements. They stated calmly that they would repay their bank loans sak legane (when I get the chance), after fulfilling their various social obligations (Semedi 1991: 207). By now, this order has been reversed. People procure larger portions of their capital through bank loans than through these various other arrangements; they feel bound to repay their bank loans first, before attending to other obligations, and finally, the principles of the banking system above all, self-responsible, punctual repayment - are increasingly applied to diverse types of borrowing and lending arrangements. Those who fail to repay their debts on time suffer shame and social stigma. This would have been different in the 1980s or 1990s, when the values of the banking system were not yet internalized and generalized to other types of financial relations.

Thus, the enclosure of fisheries that has been achieved in North America by the mechanism of individual transferable

\footnotetext{
$\overline{33}$ Ethnographic studies have shown that fishing people in Southeast Asia have been using multiple and intricate systems of credit and debt, saving and withdrawing for a long time. See e.g. Firth 1946; Szanton 1972; Niehoff 1985; Masyhuri 1996; Semedi 2003; Adhuri 2013.

34 Jay 1969; Alexander 1987; Koning 2004; Beatty 2009. Contributions to life cycle rituals among fishers in Wonokerto in the 1990s were: Rp 5.000 for a neighbour; Rp 50.0000 for a relative; Rp 100.000 for siblings. These days the sums have grown to Rp 50.000 for neighbours to one million rupiah.
} 
quotas (e.g. Pinkerton 2013, Pinkerton and Davis 2015; Knott and Neis 2016; Edwards and Pinkerton 2019) has been achieved on the Java north coast by means of smallscale and micro-credit schemes (Adam and Lestari 2017). While Pomeroy et al. (2020) have recently argued in favour of such schemes, arguing that "financial inclusion" reduces the vulnerabilities of fishing households, our observations from the cantrang fishery lead us to take the opposite stance. Cantrang fishers' financial inclusion has been a debt trap, and the increasing indebtedness of households and the subordination of relations of mutual financial support to banking principles has rendered not just fishing businesses but also social reproduction in the fishing villages extremely vulnerable. ${ }^{35}$ As we will show below, the cantrang ban did not interrupt, but provided a further occasion for the extension of bank loans and indebtedness (see e.g. Bank Indonesia 2016), this time ostensibly to help fishers transition to new gear.

Fishers were active participants, and some of them were eager proponents of relations of "cooperation", as they called it, with the banks. They perceived as an opportunity what we, as ethnographers, perceived of as the forceful inclusion of fishery in the market through the mechanism of debt (see McCarthy 2010). They wanted to become rich fast. The cantrang was perfectly suited to this end, because it could be used year round and targeted a broad range of demersal species, large and small, for which demand was high. In addition to this motive, however, we suggest that a second one is equally or more important. Fishers, who had long been socially, culturally and politically marginal in predominantly agrarian Java, wanted to engage as full citizens in the modern nation state. They wanted to be able to come and go in urban office buildings, and to get to know people and opportunities beyond the world of the fishing hamlets. Their cooperation with the banks offered them this opportunity, just as the fishing organisations had to their grandfathers in the early twentieth century. But while their grandfathers had accessed these opportunities by becoming clients of a paternalistic state, the condition for fishers to enjoy them now was that they become proper market subjects. They had to behave as calculating individuals, self-responsible for repaying their debts on time. Their efforts were frustrated when in 2015, the government intervened in the rapid growth of the fleet and announced that the use of the cantrang and related gear types would be prohibited.

\footnotetext{
${ }^{35}$ See Isnaini (2013) on the financialization in farmer's households in the north coast of Java. In-depth ethnographic studies of the financialization of households and neighbourhoods are available for diverse settings, including Han's (2012) from Chile, Li's (2014) from Sulawesi and James' (2015) from South Africa.
}

\section{The cantrang ban and the transition period}

The reasons cited for this intervention - the third we discuss in this paper - were environmental (Ambari 2017; Lelono and Bintoro 2019). Stock assessments suggested that demersal stocks of the Java Sea were being over-fished. ${ }^{36}$ Since 2013, local fisheries officials had been conducting consultations (sosialisasi) with boat owners to inform them that the government was preparing to intervene in the rapid and poorly documented growth of the cantrang fishery (Tempo 23/02/2015). They explained to fishers that the cantrang were not environmentally friendly (tidak ramah lingkungan). Specifically, they highlighted three problems with their gear, from the perspective of the government: First, because of their fine mesh size, fish (and not only fish) of all sorts and sizes got caught in their nets; second, the use of the net had destructive effects on the seafloor, and third, the fish stocks in the Java Sea were already declining because of overproduction. Fishers at Batang, however, did not expect that the government would act on those concerns by "putting fish over people", as they commented bitterly in 2015 . They were expecting attempts to enforce fishing zones or similar kinds of action, but they were not expecting a total ban on the use of their gear, among others. They were especially disappointed in the Minister of Marine Affairs of Fisheries, Susi Pudjiastuti, who had started her career as a fish trader. She had taken radical action against foreign trawlers (Kompas 13/11/2016), which the cantrang fishers had applauded. They had not imagined that she would turn against them with equally radical measures.

The announcement of the ban on January 9, 2015 came during the west monsoon, when most boats were in port because of bad weather. It granted all fishers a transition period of three months, during which to exchange their newly prohibited gear with a more environmentally friendly gear type. The cantrang boats - the main target of the measurewere to be re-registered and re-measured. Cantrang fishers at Batang were incredulous. They accused the Minister of Marine Affairs and Fisheries of trying to sharpen her political profile at the cost of fishers, whose livelihoods were on the line. Fishers' organisations, old ones and newly constituted ones, organized demonstrations. On 25th January and 3rd March, they blocked the Java north coast. On 26th February, they protested in front of the Presidential Palace in Jakarta (see Detik 26/02/2015; 03/03/2015; 04/03/2015; Kompas 23/02/ 2015; 04/03/2015; BeritaSatu 03/03/2015).

\footnotetext{
$\overline{36}$ Prisantoso (2011:70) presents the following demersal catch statistics for the Java Sea: 1985: 225.051 ton in 1985, 409.000 ton in 1995, 486.400 ton in 2005 , and 538.229 ton in 2008 . The maximum sustainable yield was estimated to be 431,200 ton, and the total allowable catch 345.000 ton (ibid.:73). His field observations suggest a declining quality of the catch, with the average size of individual fish decreasing. Fish traders at Batang reported the same observation to us. The Minister of Fisheries mentioned the decline in the size of fish as a reason for the cantrang ban in one of her public statements (Suara Merdeka 15/11/2017).
} 
In other ports along the Java north coast, more affluent boat owners sought legal aid, and from those ports, especially from Rembang, news about an emergent national campaign travelled to the cantrang fishers at our field site at Batang. The campaign took a three-pronged approach. First and most urgently, the fishers' representatives worked toward an extension of the transition period, citing procedural faults and successfully involving the national ombudsman in their case. After several provisional renewals of the transition period, the period was eventually extended by decree in October 2016 to last until December 2017 (GoI, Minister of Marine Affair Circular Letter No. 72/MEN-KP/II/2016). Fishers' second demand concerned financial support for changing gear, which the government was generally willing to provide. Credit schemes for the owners of small boats (below 10GT) began in 2016; in early 2017, the Central Javanese governor broke the news to fishers at Batang that local governments would set up a further credit scheme to assist fishers in changing their gear. ${ }^{37}$ Further negotiations at the presidential palace in July 2017 led to further concessions, among others, credit opportunities for owners of boats above 30GT. Third, fishers and their representatives set about dismantling the government's main argument, repeated over and again in the press, for banning the use of the cantrang and related gear. They challenged the claim that the cantrang damaged the environment (see also Detik 18/05/2017; Suara Merdeka 02/10/2017, $13 / 10 / 2017,23 / 12 / 2017)$. Specifically, they rejected the government's lumping together of cantrang and trawl in a single category of "environmentally unfriendly" fishing gear. During negotiations at the Presidential Palace in June 2017, they made an environmental impact assessment of the cantrang one of their conditions for accepting the ban (Detik 11/07/ 2017a, 11/07/2017b; Suara Merdeka 02/11/2017, 13/11/ 2017). After the impact assessment turned out inconclusive, and after further demonstrations in January 2018, the prohibition of the cantrang and related gear was postponed indefinitely for fishers in northern Java, specifically, for the districts of Tegal, Batang, Pati, Rembang, Lamongan (Detik 18/01/ 2018; see also: Radar Pekalongan 23/12/ 2017; Suara Merdeka 31/03/2018). The condition of re-measuring all boats remained, however, and the government announced that no new permits for cantrang would be issued.

The long period of negotiations and uncertainty had caused Batang's cantrang fishers financial and emotional hardship. Besides crew members, captains and boat owners, large numbers of people working in fish trading, processing and auxiliary industries were affected. Many households of ordinary crew members in the fishing hamlets lost two or

\footnotetext{
${ }^{37}$ GoI, Minister of Marine Affair Circular Letter B.1/SJ/PL.610/I/2017; this decision stood in the context of an expansion of micro-credit schemes, including one survey specifically recommending them for fishing people (Bank Indonesia 2016).
}

more incomes, as the men worked on the boats and the women in the processing industry. Some fishers shifted to work on mini-purse-seines and small-scale boats that were also operating out of the port, but many others were grounded and struggled to pay children's school fees and living expenses for their households. Inner-household relations became strained as a result, as well. Boat owners, though ostensibly with much more money to spare, were stuck in debts and with boats whose price dropped precipitously after the announcement of the ban. ${ }^{38}$

Nevertheless, fishers in Batang were less visible in fisher activism at the national level than cantrang fishers at other ports. In 2015, many of them joined the early demonstrations at their port, on the Java north coast road and in Jakarta. However, they quickly distanced themselves from the physical violence at some demonstrations. Some complained that outsiders were manipulating fishers' anger and frustrations. Over time, many were also increasingly upset with what they perceived as an opportunistic attitude of newspapers and political parties toward their plight (see also Suara Merdeka 09/01/2018; 28/04/ 2018). More interestingly, from our perspective, Batang fishers' perceptions of the ban, their assessment of their situation and their priorities, both short-term and more long-term, did not sit easily with a campaign that was aiming to restore the cantrang fishery. Restoring the cantrang fishery was, to be sure, the stated wish and demand of the vast majority of fishers at Batang, too. However, the actual responses of boat owners to the ban suggest that most were busy, one by one rather than collectively, to find a way out of a fishery that many knew was only viable under conditions of maximal neglect by the government. To run cantrang boats profitably, as these fishers knew very well, was not possible within existing regulations pertaining to fishing zones and specifications for obtaining permits for boats. Thus, as soon as the government decided to pay attention, they reckoned that the "era of the cantrang" was over. Like other "exiting elites" before them, they were seeking alternative opportunities; those who could not find any, mostly because their burden of debt was too heavy, suffered anxiety and depression as a result and did not find solace in joining demonstrations. In the following section, we present some ethnographic details to support this conclusion, which is ours and not that of fishers themselves.

\footnotetext{
${ }^{38}$ The prices of boats fluctuated over the 3-year "transition period", as at low points (for the fishers) in the negotiations, buyers from all over Indonesia descended on the large cantrang ports looking for desperate owners willing to sell their boats for next to nothing.
} 


\section{Responses of the cantrang elite}

Based on our conversations with boat owners at Batang and our observations of their business activities since 2013, we distinguish between three categories of owners, differentiated by the size and number of their boats and their non-maritime assets. These factors made different lines of action available and attractive to them after the announcement of the ban. Not all owners within a particular category pursued those options. If, how fast and how vigorously they took them up, depended on personal networks, experiences and inclinations.

The first category of boat owners is small but influential. It consists of six extremely well-to-do owners out of a total of perhaps 120 . Three of them are sons, and another is a son-inlaw of a single successful beneficiary of the 1980s KIKscheme. The other two later arrivals who had benefited from the profitability of the cantrang. Their households were economically secure. They owned rice-land or fruit orchards and urban real estate in addition to their boats. Besides owning several large cantrang boats, two of them also owned one large purse seiner, and one of them owned two purse seiners. Those purse seiners were operating in Eastern Indonesian waters and sold their catches either at sea or at the port of Pekalongan. They were more profitable for their owners than the cantrang boats, and their gear was deemed environmentally friendly. The only reason why so few people owned large purse seiners at Batang was that the original investment required was very high, because they required freezers. ${ }^{39}$

Those among the top six owners who had transitioned to purse seining before 2015 were relatively mildly affected by the cantrang ban. They suffered losses, but their businesses were viable even without their cantrang boats. For the ones who did not own purse seiners yet, the priority after the ban was to speed up the transition, which was usually a matter of negotiating with the banks. One of them also invested in a gill net. The gill net was the second type of "environmentally friendly" gear that the fisheries officials advocated for large boats, and like purse seiners, only the most affluent owners could afford it because it required a freezer. Unlike purse seiners, gill netters could operate in the Java Sea, legally and profitably, but there were no captains and crew at Batang who knew how to operate them. Thus, Batang owners hired captains and crew members from Indramayu (West Java), where gill netting was common. Their negotiating position, both visa-vis their initial contacts and agents at Indramayu and against captains and crew was very weak. The first gill net owner from Batang stood by helplessly as his crew from Indramayu abandoned the boat after what was supposed to be half of its time at sea, carrying the supplies (fuel, food etc.) with them to sell at

\footnotetext{
$\overline{39}$ A purse seiner with a freezer cost about six billion rupiah in 2015 , while a cantrang cost between 800.000 and 1.2 billion. Therefore only owners with several highly productive cantrang could make the leap.
}

home. They argued that the catch was too poor for them to complete the trip. Although this particular owner's business survived, other owners, who had been observing his trials with a keen interest, opted against a gill net, citing his difficulties.

For this group of owners, the gains of the national campaign with respect to financial support for fishers with boats above 30GT in size were helpful but, according to our knowledge, not essential. The campaign's focus on rehabilitating the cantrang boats was not a priority. This group of owners, most of whom had been among the first to adopt the cantrang, had already moved on. The one exception among the six was an owner known for his ambition to become a prominent, influential community leader among the fishers. He took the lead in forming a new fishers' organisation, called Front Nelayan Batang Bersatu (United Front of Batang Fishers), through which he supported the aims and strategies of the national campaign. Lacking support from other owners, who did not trust him because, unlike them, he had the necessary assets that would allow him to opt out if necessary, the organisation remained a one-man show until early 2019.

Unlike the top six owners, boat owners in the second category could not move on so easily, because they were heavily invested in the cantrang fishery. They were living well, many of them in new, comparatively large houses and with one or more cars. However, they relied for their income exclusively or almost exclusively on their large or medium-size cantrang boats, often complemented by boat building or cantrangdependent processing businesses. Many of these owners had experienced precarious ups and downs in their businesses before the cantrang ban, and most were heavily indebted. When the Minister of Marine Affairs and Fisheries banned the use of their boats, their businesses stalled. It is not surprising that many vocal opponents of the ban, including some of the few who actively supported the national campaign came from this category of owners. The campaign met their goals: extending the transition period, making funding available, but finally, not transitioning to another gear type but keeping their cantrang boats running.

Some of these owners set up their own fishers' organisation, the Association of Traditional Fishers in Batang (Paguyuban Nelayan Tradisional Batang). They presented themselves as small-scale fishers who had done exactly what was expected of them: to develop the entrepreneurial visions and skills to set up and run productive businesses. On those grounds, they demanded that they should not be cut off, but supported by the government (see also Suara Merdeka 17/09/ 2017). These cantrang owners argued that the government, when it blamed the cantrang boats for damaging the seafloor, were mistaking cantrang boats for trawlers, in environmental terms but also socially. With respect to the environmental dimension, they echoed and further specified demands of the national campaign for the government to prove that the cantrang was indeed environmentally harmful. They 
suggested that the government had failed to take into consideration the technical differences between cantrang (laid out in a semi-circle on the sea floor and then lifted) and trawl (dragged along the sea floor). They added that, should the cantrang indeed prove environmentally harmful, then they would be willing to give it up, but only if the government could suggest a viable alternative. Less publicly, they complained that the government was mistaking their options as cantrang owners with those of the trawler owners of the past. Here, the ethnic stereotypes were revived again that the government itself had promoted in the 1980s. Cantrang owners suggested that the trawler owners of the past could easily shift their capital because they were Chinese and therefore did not face the same capital constraints as Javanese small-scale fishers; they themselves, by contrast, did not have these options. They had taken great risks in building their fleet with the help of bank loans; why would the government now punish them by rendering their boats not only unproductive but also worthless?

The day-to-day activities of these owners were consistent with their political pronouncements in favour of rehabilitating the cantrang, of their ambivalence toward a coalition led by the biggest owners and of their own financial hardships. They were busy re-negotiating bank loans, selling one or several cars, and selling unproductive boats if they could find buyers. Their immediate concern, from 2016 onward, was to have their boats pass the compulsory re-measurement to make sure that all boats were below 30GT. Most boats were, in fact, larger, and their owners had to find creative solutions. One owner nailed the two storage rooms in the back of his boat shut; because of the peculiar shape of his boat, the officials did not notice and his 50GT boat, until then running on a 23GT permit, passed for 32GT and was permitted to continue running. Another way around the problem of re-measurement, risky but common, was to acquire legal permits for boats that would not pass the re-measurement process, and keep them in operation on those permits. A lively trade in permits for sale or lease set in. Some boat owners whose boats had not been running well but who were well-connected and trusted by their peers became full-time agents of permits (see also Kompas 19/06/2015). Many owners, however, also suffered stress and boredom as their boats were grounded. One man whom we had known as an active and enthusiastic owner of two boats and builder of many others spent his days on the beach, angling. Another started breeding fighting fish (ikan cupang, Betta sp.) for national competitions. Yet others among the male owners involved themselves in the businesses of their wives, some of whom ran small stores from their homes or online. ${ }^{40}$

\footnotetext{
${ }^{40}$ In the "ordinary" times before the ban, the women themselves and their husbands used to downplay these activities. They preferred to give the impression that the women in the household did not have to work (Schneider 2018). After the cantrang ban, the contribution that these "time-fillers" or "little sidebusinesses" made to household incomes became more visible.
}

Our conversations with boat owners from this group suggest that many of them were becoming increasingly aware during the transition period that with or without the ban, the cantrang fishery was facing serious problems. There were technical limitations that could not easily be overcome. Boat owners were aware that they could only significantly expand their range or operation, access rich fishing grounds and increase their income by equipping their boats with cold storage units, which required a major investment. There was no obvious solution to these technical problems, and owners whose capital was bound up in their now unproductive boats and with bank loans to repay did not see themselves in a position to experiment. With plenty of time for reflection in the transition period but no capital to seek out alternatives, many owners thus became gloomy, while others turned their anger against the government and demanded "a solution" from those in power. This phrase appeared over and over in our conversations with boat owners between 2015 and 2018 (see also Suara Merdeka 17/9/2017, 08/01/2019). Many of them switched back and forth during those years between gloominess and demands for a solution, expressed sometimes calmly, sometimes furiously.

Yet more acutely aware of those underlying problems of the cantrang fishery, and of the impossibility not just of expansion but also of running cantrang boats within the limits of what was currently legal were owners of a third category. They were known locally as "small" owners, the owners of boats that indeed were below 30GT in size. For several years, they had experienced not only highly uncertain catches, but also declining returns from their boats. Because their boats could not travel far, they knew that near-shore fish stocks were already depleted. Unlike the owners of larger boats that travelled further, they had evidence of this, along with evidence of the declining returns from their boats, black on white. They knew already before the ban that their businesses had reached a dead end. A few owners from this category were already actively seeking a way out of the fishery in 2013, when we began fieldwork in the cantrang villages.

One of these actively diversifying owners was the daughter of a small-scale fisherman and a fish trader, now 39 years in age, who had fought hard to complete vocational school and learn accounting. After completing her education, she took over her parents' boat and used her accounting knowledge, maximised her own labour power as well as family contacts to keep it in business and added a second one. At the same time, she took out a bank loan for diversifying her business. As a first attempt, she bought a truck that she rented out to transport goods within Jakarta's commercial port area. A friend in Jakarta supervised the truck, and they shared the profits. The income was low, and so she kept searching for other options. Online, she read stories of small investors like her who had profited from recycling plastic, and in 2013, she set up her own recycling business. Together with her husband, she hired 
people to collect bottles in the fishing villages, rented a workspace to sort the plastic, taught herself the relevant categories, qualities and market prices and negotiated with a recycling plant that was willing to buy her bottles. She gave up on this business in 2015 because the sellers and buyers of bottles took advantage of her inexperience. Laughing, she commented that she knew all about fish, from the time when she was small, but plastic was a whole new world in which she had to start out with baby steps.

This owner, along with a few others like her, perceived the cantrang ban at least as much as an opportunity as a threat. When the government announced funding for cantrang owners willing to convert their boats into gill nets, she stepped forward. She took out a loan of 600 million (about 40.000 US\$) rupiah for a gill net and tried to run her boat with it. However, she encountered the same problem as the largescale gill net owner: agents, captain and crew from Indramayu whom she depended on for running this boat turned out unreliable. She tried to run the boat with half its crew from Indramayu and the other half from Batang, but the two parts of the crew started arguing at sea, broke off the trip, returned to shore and carried the supplies home. After two fishing trips, it turned out that a both of 30 gross ton with a relatively small gill net could not compete with the larger gill nets for income, and thus also for labour that was scarce in this fishery, too. This owner was left with her 40,000 US\$ debt, added to an outstanding one of about 14.000 US\$ from the time before the ban. She lacked a source of income and suffered serious symptoms of stress. When, in 2018, the government finally decided to exempt the ports on the Java north coast from the ban on the cantrang, she felt let down. Furiously, she complained about the government's "plin plan", its change of mind. In her case, the government had effectively repelled one potential member of a new, "environmentally friendly" elite that might have helped them implement environmental sustainability as a governance principle in the Java north coast fisheries.

\section{Conclusion}

To summarize our key findings, one point of contrast between the cantrang ban and previous interventions concerns the social, political and economic position of the established elites and their ability to transfer their capital out of the fishery; another is the readiness of new elites to assume their role as local bearers of a new governance principle. In 1905, the established elite targeted by the intervention were predominantly Chinese entrepreneurs. Historical sources consistently emphasize their ethnic difference, and so do the fishers in our field sites. As ethnic "others", they were easy targets for the accusation of exploiting (ethnically Javanese) small-scale fishers who deserved the colonial state's protection; conversely, it was relatively easy and attractive for them to pull their capital out of the fishery when the government intervened. The intervention was successful insofar as the Chinese entrepreneurs did indeed withdraw from their formal role as local patrons and creditors to fishers. But neither these elites nor the reliance on personalized patronage disappeared from the fishery entirely. Chinese entrepreneurs remained active as traders; for better understanding their recent history, ethnographic research along their trade routes, beyond the fishing villages in which we have worked so far is required. Fishers, in the meantime, developed relations of personalized patronage with members of the new elites, whom the government had identified and installed in formal leadership positions in the fisheries organisations and whom it continued to support. In their official positions as organisation managers, the latter represented the new governance principle of statesponsored protection of the state. However, personalized relations were required for fishers to access these sources of state funding and protection. Thus, the implementation of the new governance principle was neither complete nor even across locations and specific social circles in the villages.

In 1980, the New Order government successfully framed what was effectively the removal of state protection for smallscale producers as an act of support for ethnically Javanese small-scale fishers against Chinese investors in the commercial trawler fishery. As our analysis shows, this is a highly selective portrayal of the situation, although it may have lent legitimacy to the intervention. Based on our ethnographic data, Javanese trawler owners who lived in the fishing villages in Batang and Pekalongan switched to purse seining, although this turned out to be a temporary solution. While they certainly suffered losses, their "mixed" (trawling and purse seining) businesses were not immediately threatened. Moreover, both the general political climate and their physical and social proximity to small-scale fishers who welcomed the ban would have made it difficult for them to openly oppose the ban. By the time purse seining became unprofitable in the mid-1980s (Batang) to mid-1990s (Pekalongan), these owners were able to exit the fishery without a decline in status, thanks to the opportunities that their children had acquired through education. In fact, the social standing of their families increased as a result, since the white-collar and civil servant jobs that their children acquired had a cultural value that surpassed even that of a successful fishing business. Looking beyond those local owners, our sources suggest that in the long-term, the adverse effects on Chinese and on large-scale businesses were less significant than the fact that the trawler ban accelerated small-scale fishers' inclusion in the market. Put differently, rather than a renewed commitment to the protection of small-scale fishers, the trawler ban accelerated the extension of market principles to small-scale producers, and for making economic development based on market principles the key governance principle for small-scale fisheries. Following the trawler ban, the installation of new elites, who impersonated the new 
principle of (un-)regulating small-scale fisheries by linking them directly with financial, fish and maritime labour markets, took time. From our perspective, the new fisher-entrepreneurs only became firmly established thanks to the capital influx during the monetary crisis of the late 1990s. They thrived in the early 2000 s, but by the 2010 s, their economic success was perceived as a problem by fisheries officials.

The 2015 cantrang ban lacked the ethnic dimension of earlier government interventions. In this case, the elites that were being pushed out of the fishery were unmistakably Javanese fishers who described themselves as small-scale, despite the size and productivity of their boats. They were ordinary people who had achieved their elite position precisely by re-fashioning themselves as entrepreneurs in a market-oriented governance system, as the previous government demanded of them after the trawler ban. When the (new) government turned against them, reasoning that their gear was not environmentally friendly, these established elites occupied the moral high ground, and the government had to fear an electoral backlash if it carried through with the ban in its political heartland. Moreover, and in contrast to previous interventions, only very few cantrang owners had the assets and capital necessary to exit the fishery. The majority of the cantrang elite was literally tied to their boats and tied to the fishery by their high levels of indebtedness. Their children were still in school, they had heavy bank loans to repay and lacked contacts, knowledge or skills that would have facilitated their transfer to another sector. Being asked to exit the fisheries without having a viable exit road (except for registering bankruptcy), they resisted, and the political conditions at the time allowed them to do so openly.

A second set of contrasts between the cantrang ban and earlier interventions concerns the role of rising elites, or local allies who would become the bearers of the new governance principle. In 1905, new, rising elites were actively identified, supported and "installed" by the colonial government. At the time of the trawler ban, the government's support for local elites who would support the new governance principle was weaker. This was, of course, consistent with the new principle of market-based growth. True to this principle, the government provided support in the form of infrastructure to local trawler and purse seiner owners in order to build their purse seining businesses. At the same time, it offered loans to smallscale fishers who were to become the new, entrepreneurial elites. After this initial support, these new elites were expected to assert themselves in the market, as indeed they did, though they only became firmly established after the Asian financial crisis. This raises the question, then, what would have been appropriate measures to support to members of a new elite who would implement the governance principle of sustainability. Furthermore, one might ask if such measures were in evidence yet by 2019 .
After the announcement of the cantrang ban, the government used the "old" form of support, credit schemes, to enlist cantrang owners to change their gear and become "environmentally friendly" fishers. Most owners were reticent. Besides general mistrust of the government because of its zigzag course between 2015 and 2019, our observations suggest that there were translation problems concerning the new governance principle, sustainability. The government kept insisting that the cantrang were harming the sea floor, a point that few cantrang fishers were willing to cede. At the same time, there were many fishers, especially "small" boat owners, who were aware that their boats had reached their technical limits of profitability, and that the cantrang fishery would not be productive in the future. Unfortunately, it appears that the consultation processes that were carried out before the cantrang ban was announced were insufficient to make these fishers visible, and to convey their concerns and awareness of existing limitations of their fishery to the government. To the contrary, with the complete ban of the cantrang and its reasoning about sustainability, the government alienated those owners. When finally, the credits offered after the ban for changing gear were made available only slowly and were apparently inadequate, as our example above has shown, the government lost whatever (mostly tacit) support it had for the cantrang ban in the fishing villages. By 2019, no prospective elites who would become the bearers of the new governance principle of sustainability had stepped forward in our field sites yet. If and by what means this will be achieved, and if it will even be attempted under a new fisheries minister, remains an open question at this point in time.

Acknowledgements Some of the ethnographic research for this paper was conducted with financial support from the Thyssen Foundation. The MA students on the team were financed through the "In Search of Balance" Project at Universitas Gadjah Mada and Agder University. We thank the anonymous reviewers at Maritime Studies for their comments and suggestions.

Funding Open Access funding enabled and organized by Projekt DEAL.

\section{Compliance with ethical standards}

Conflict of interest On behalf of all authors, the corresponding author states that there is no conflict of interest.

Open Access This article is licensed under a Creative Commons Attribution 4.0 International License, which permits use, sharing, adaptation, distribution and reproduction in any medium or format, as long as you give appropriate credit to the original author(s) and the source, provide a link to the Creative Commons licence, and indicate if changes were made. The images or other third party material in this article are included in the article's Creative Commons licence, unless indicated otherwise in a credit line to the material. If material is not included in the article's Creative Commons licence and your intended use is not permitted by statutory regulation or exceeds the permitted use, you will need to obtain permission directly from the copyright holder. To view a copy of this licence, visit http://creativecommons.org/licenses/by/4.0/. 


\section{References}

Adam, Latif, and Esta Lestari. 2017. Indonesia's guaranteed microfinance programme (KUR): Lessons from the first stage of implementation. Journal of Southeast Asian Economies 34 (2): 322-344.

Adhuri, Dedi Supriadi. 2013. Selling the sea, fishing for power: A study of conflict over marine tenure in Kei Islands, Eastern Indonesia. Canberra: ANU Press.

Alexander, Jennifer. 1987. Trade, traders and trading in rural Java. Oxford: Oxford University Press.

Ambari, M. 2017. Kenapa Alat Tangkap Cantrang Masuk Kelompok Dilarang di Indonesia? Mongabay. https://www.mongabay.co.id/ 2017/05/02/kenapa-alat-tangkap-cantrang-masuk-kelompokdilarang-di-indonesia/. Accessed 20/11/2020.

Bailey, Conner. 1988. The political economy of marine fisheries development in Indonesia. Indonesia 46: 25-38.

Bailey, Conner. 1997. Lessons from Indonesia's 1980 trawler ban. Mar Policy 21 (3): 225-235.

Bailey, Conner, and A. Dwiponggo. 1987. Indonesian marine fisheries: Structure and change. In Indonesian marine capture fisheries, ed. Conner Bailey, A. Dwiponggo, and F. Marahudin. Manila: ICLARM.

Bailey, Conner, and Firial Marahudin. 1987. The economics of marine fisheries: Costs and earnings. In Indonesian marine capture fisheries, ed. Conner Bailey, A. Dwiponggo, and F. Marahudin. Manila: ICLARM.

Bank Indonesia. 2016. Kajian Potensi Keuangan Unbanked People Pada Sektor Perikanan. Jakarta: Bank Indonesia.

Bavinck, M., and R. Chuenpagdee. 2005. Current principles. In Fish for life: Interactive governance for fisheries, ed. J. Kooiman, M. Bavinck, S. Jentoft, and R.S.V. Pullin, 245-265. Amsterdam: Amsterdam University Press.

Bayyinah, Aulia A.L., Ismail, and Trisnani Dwi Hapsari. 2014. Analisis Finansial Usaha Perikanan Tangkap Cantrang 30 GT di Pelabuhan Perikanan Pantai (PPP) Tasik Agung, Rembang. Journal of Fisheries Resources Utilization Management and Technology 3 (3): 218-227.

Beatty, Andrew. 2009. A shadow falls: In the heart of Java. London: Faber and Faber.

Besseling, O.P. 1913. De Visschersvereeniging te Tegal. Batavia: Javasche Boekhandeld \& Drukkerij.

Blink, H. 1926. De Inlandsche Landbouw in Nederlandsch Indie. Utrecht: De Nederlandsche Vereeniging voor Economische Geographie.

Boeke, J.H. 1936. Inleiding tot de Economie der Inheemsche Samenleving in Nederlandsch-Indie. Leiden-Amsterdam: H. E. Stenfert Kroese's Uitgevers-Mij H.v.

Boomgaard, Peter. 1989. Children of the colonial state. Amsterdam: Free University Press.

BPS (Biro Pusat Statistik). 1980. Indonesia Annual Statistics 1980. Jakarta: Biro Pusat Statistik.

BPS (Biro Pusat Statistik). 1990. Indonesia Annual Statistics 1990. Jakarta: Biro Pusat Statistik.

Butcher, John. 2004. The closing of the frontier: A history of the marine fisheries of Southeast Asia, c. 1850-2000. Singapore: Institute of Southeast Asian Studies.

Butcher, John, and Howard Dick. 1993. The rise and fall of revenue farming. In Business Elites and the Emergence of the Modern State in Southeast Asia. New York: St. Martin Press.

Chuenpagdee, Ratana, and Svein Jentoft. 2018. Transforming the governance of small-scale fisheries. Maritime Studies 17 (2018): 101115 .

Collier, William L., Harjadi Hadikoesworo and Suwardi Saropie. 1977. Income, employment, and food systems in javanese coastal villages. Athens, Ohio: Ohio Univ. Center for International Studies.
Comitini, Salvatore, and Sutanto Hardjolukito. 1983. Indonesian marine fisheries development and strategy under extended maritime jurisdiction. Honolulu: East-West Center.

Damayanti, Onesya. 2016. Donyane wong mbelah ojo turun anak putu. Mobilitas sosial nelayan jukung di batang, jawa tengah. Master thesis. Yogyakarta: Dept. of Anthropology, Universitas Gadjah Mada

Daryanto. 2011. Sistem Akuntansi Penggajian pada Pusat Koperasi Unit Desa (PUSKUD) 'Mina Baruna' Jawa Tengah. BA thesis. Semarang: Jurusan Akuntansi D3 Fakultas Ekonomi Universitas Negeri Semarang

De Visscherij Tijdschrift. 1930. "Algemeen gedeelte. Vischveiling te Batavia". No. 23 1930. pp. 231-233.

De Waart, K. 1924. Een groote toekomst voor de visscherij in N.O.I? Tijdschrift de Visscherij. Vol. 4 No. 6, pp. 60-66.

Directeur van Onderwijs. 1904. Rapport van den directeur van onderwijs, eeredienst en nijverheid betreffende de maatregelen in het belang van de Inlandsche nijverheid op Java en Madoera in verband met de door het moederland voor dit doel beschikbaar te stellen fondsen, 1904. Batavia: Landsdrukkerij.

Durrenberger, P. 1988."Shrimpers and turtles on the Gulf Coast: The formation of fisheries policy in the United States" in MAST Vol 1 (2).

Edwards, Danielle N., and Evelyn Pinkerton. 2019. The hidden role of processors in an individual transferable quota fishery. Ecology and Society 24 (3): art36.

Ernawati, Tri; Nurulludin, Nurulludin and Atmadja, Suherman Banon. 2011. Produktifitas, Komposisi Hasil Tangkapan dan Daerah Penangkapan Jaring Cantrang yang Berbasis di PPP Tegalsari, Tegal. Jurnal Penelitian Perikanan Indonesia. Vol.17 No. 3, pp. 193-200.

Fauda, Noviati, Sri Muljati, and Agus Triwinarto. 2018. Sumbangan ikan laut terhadap kecukupan konsumsi protein penduduk Indonesia. Penelitian Gizi dan Makanan 41 (2): 77-88.

Fernando, M.R. 2010. The worst of both worlds: Commercial rice production in West Indramayu, 1885-1935. Journal of Southeast Asian Studies 41 (3): 421-448.

Firth, Raymond. 1946. Malay fishermen: Their peasant economy. London: Routledge and Kegan Paul.

Furnivall, J.S. 2010 [1939]. Netherlands India. A study of plural economy. Cambridge; Cambridge University Press.

Hainsworth, G. 1985. Economic growth, basic needs and environment in Indonesia: The search for harmonious development. Southeast Asian Affairs 1985: 152-173.

Hakim, L., Nurhasanah. 2016. Cantrang: Masalah dan Solusinya. In Proceeding of Seminar Nasional Riset Inovatif 4. Jakarta: Ministry of Research and Technology.

Hamid, Edy Suandi. 1988. Gambaran Beberapa Kasus Kredit Pedesaan di Jawa Tengah. Jurnal Unisia XII (2): 76-88.

Han, Clara. 2012. Life in debt: Times of care and violence in neoliberal Chile. Berkeley: University of California Press.

Hatta, Mohammad. 1957. The co-operative movement in Indonesia. Ithaca: Cornell University Press.

Higgins, Benjamin. 1958. Hatta and co-operatives: The middle way for Indonesia? The Annals of the American Academy of Political and Social Science 318: 49-57.

Irwan, A. 2005. Institution, discourses and conflicts in economic thought. In 2005. Social Science and Power in Indonesia, ed. V.R. Hadiz and D. Dhakidae, 31-56. Jakarta: Equinox.

Isnaini, Zuli Laili. 2013. Dodolan Kolor. Jolok, Resiliensi Ekonomi Rumah Tangga Desa. Master thesis. Yogyakarta: Dept. of Anthropology, Universitas Gadjah Mada.

James, Deborah. 2015. Money from nothing: Indebtedness and aspiration in South Africa. Stanford, CA: Stanford University Press.

Jay, Robert. 1969. Javanese villagers: Social relations in rural Modjokuto. Cambridge, MA: MIT Press. 
Kahin, George McT. 1946. The Chinese in Indonesia. Far Eastern Survey 15 (21): 326-329.

Knott, Christine, and Barbara Neis. 2016. Privatization, financialization and ocean grabbing in New Brunswick herring fisheries and salmon aquaculture. Marine Policy Vol 80: 10-18.

Koning, Juliette. 2004. Generations of change: Migration, family life, and identity formation in a Javanese Village during the new order. Yogyakarta: Gadjah Mada University Press.

Kooiman, J. 2003. Governing as governance. Thousand Oaks: SAGE.

Kooiman, J. 2005. "Introduction" to part IV. In Fish for life: Interactive governance for fisheries, ed. J. Kooiman, M. Bavinck, S. Jentoft, and R.S.V. Pullin, 241-244. Amsterdam: Amsterdam University Press.

Kooiman, J., and S. Jentoft. 2005. Hard choices and values. In Fish for life: Interactive governance for fisheries, ed. J. Kooiman, M. Bavinck, S. Jentoft, and R.S.V. Pullin, 285-299. Amsterdam: Amsterdam University Press.

Kooiman, J., S. Jentoft, M. Bavinck, R. Chuenpagdee, and R.U. Sumaila. 2005. Meta-principles. In Fish for life: Interactive governance for fisheries, ed. J. Kooiman, M. Bavinck, S. Jentoft, and R.S.V. Pullin, 265-284. Amsterdam: Amsterdam University Press.

Krisnandhi, Sulaiman. 1969. The economic development of indonesia's sea fishing industry. In Bulletin of Indonesian Economic Studies. Vol. V. No. 1, 49-72.

Lelono, Tri Djoko, and Gatut Bintoro. 2019. Risk analysis approach of trawler (seine nets fishing boats) in north coast of East Java. Journal of Fisheries and Marine Research 3 (2): 263-272.

Li, Tania. 2007. The will to improve. Durham: Duke University Press.

Li, Tania. 2014. Land's end. Durham: Duke University Press.

Masyhuri. 1996. Menyisir Pantai Utara. Jogjakarta: Pustaka Nusatama and KITLV.

McCarthy, Peter. 2010. Processes of inclusion and adverse incorporation: Oil palm and agrarian change in Sumatra, Indonesia. J Peasant Stud 37 (4): 821-850.

McLeod, Ross. 1997. Survey of recent developments. Bull Indones Econ Stud 33 (1): 36-38.

Niehoff, Anke. 1985. Women and fertility in Madura (Indonesia), PhD thesis. Leiden: Leiden University.

Pauly, D., P. Martosubroto and J. Saeger. 1996. The Mutiara 4 surveys in the Java and southern South China Seas, November 1974 to July 1976 [Survei Mutiara 4 di Laut Jawa dan bagian selatan Laut Cina Selatan. November 1974 hingga Juli 1976] in D. Pauly and P. Martosubroto (eds.) Baseline studies of biodiversity: the fish resources of Western Indonesia. Jakarta; Eschborn; Manila: Directorate General of Fisheries; German Agency for Technical Cooperation; International Center for Living Aquatic Resources Management.

Pinkerton, Evelyn. 2013. Alternatives to ITQs in equity-efficiency-effectiveness trade-offs: How the lay-up system spread effort in the BC halibut fishery. Mar Policy 42: 5-13.

Pinkerton, Evelyn, and Reade Davis. 2015. Neoliberalism and the politics of enclosure in North American small-scale fisheries. Marine Policy. Vol. 61: 303-312.

Pomeroy, Robert, Carlos Arango, Cristopher G. Lomboy, and Steve Box. 2020. Financial inclusion to build economic resilience in small-scale fisheries. Mar Policy 118 (2020): 103982.

Poortman, H.H.J. 1930. De Grootvisscherij door de Japanners in onzen Oost-Indischen Archipel. In de Visscherij No. 34.

Potier, Michel, and B. Sadhotomo. 1995. Seiners fisheries in Indonesia. In Biodynex: Biology, dynamics, exploitation of the small pelagic fishes in the Java Sea, ed. Michel Potier and S. Nurhakim, vol. 1995, 49-66. Jakarta: Agency for Agricultural Research and Development.

Prisantoso, Budi Iskandar. 2011. Assessment and management of the dermersal fisheries of the Java Sea, Indonesia. Master of Maritime Studies thesis, Faculty of Law, University of Wollongong.
Priyono, B.E. 2003. Socioeconomic and bioeconomic analysis of coastal resources in Central and Northern Java, Indonesia. In G. Silvestre, L. Garces, I. Stobutzki, M. Ahmed, R.A. Valmonte-Santos, C. Luna, L. Lachica-Aliño, P. Munro, V. Christensen and D. Pauly (eds.) Assessment, management and future directions for coastal fisheries in asian countries. Conference Proceedings 67. Penang: WorldFish Center, p. 479-516.

Purdey, Jemma. 2006. Anti-Chinese violence in Indonesia: 1996 - 99. Singapore: NUS Press.

Schneider, Katharina. 2018. Gendered modes of evaluating work in a Javanese fishery. Ethnoscripts 19(2). https://journals.sub.unihamburg.de/ethnoscripts/article/view/1175.

Semedi, Pujo. 1991. Indebtedness and boat credit program. A case study of small-scale fishermen in the northern coast of Java. MA thesis. Manila: Ateneo de Manila University.

Semedi, Pujo. 2003. Close to the stone, far from the throne. Yogyakarta: Benang Merah.

Semedi, Pujo. 2005. Depletion of Java Sea's fish stock, 1850-2000. Humaniora. 17 (1): 2005.

Semedi, Pujo, Hira Jhamtani, and Tejo Wahyu Jatmiko. 2003. Revolusi Biru: menebar udang, menuai bencana. Jakarta: Konphalindo.

Simpson, B. 2009. Indonesia's 'accelerated modernization' and the global discourse of development, 1960-1975. Dipl Hist 33 (3): 467-486.

Song, Andrew M., Ratana Chuenpagdee, and Svein Jentoft. 2013. Values, images, and principles: What they represent and how they may improve fisheries governance. Mar Policy 40 (2013): 167-175.

Studyanto, Budi. 1986. Analisa sosial ekonomi nelayan peserta program kredit massal perikanan. BA thesis. Bogor: Institut Pertanian Bogor.

Sutherland, Heather. 1979. The making of a bureaucratic elite: The colonial transformation of the Javanese Priyayi. Canberra: Asian Studies Association of Australia.

Szanton, Maria Cristina Blanc. 1972. A right to survive: Subsistence marketing in a lowland Philippine town. University Park: Pennsylvania State University Press.

ten Hage, H. 1910. De Zeevissherij in Nederlandsh-Indie. Tijdschrift voor Economische Geographie 1:101-113.

Van Kampen, P.N. 1923. Visscherij en Vischteelt in Nederlandsch-Indie. Haarlem: H.D. Tjeenk Willink \& Zoon.

Van Klinken, Gerry, and Ward Berenschot. 2014. In sear of middle Indonesia: Middle classes in provincial towns. Leiden: Brill.

Wertheim, W.F., and The Siauw Giap. 1962. Social change in Java, 1900-1930. Pac Aff 35 (3): 223-247.

White, Benjamin. 1973. Demand for labor and population growth in colonial Java. Hum Ecol 1 (3): 217-236.

\section{Daily/Weekly}

Tempo

16/04/2000. "Jaring Cendana di kapal Perompak".

23/02/2015. "Larangan Menteri Susi Dilanggar, Produksi Ikan Turun Separuh"

Algemeen Handelsblad voor Nederlandsch-Indië n.d.

23/08/1939. "Regentschap Pekalongan. Inkomsten eerste halfjaar 1939".

BeritaSatu.com

03/03/2015. "Demo Nelayan di Batang Berlangsung Rusuh". https:// www.youtube.com/watch? $\mathrm{v}=\mathrm{tVFee} 2 \mathrm{~S} 4 \mathrm{XqI}$

Bisnis Indonesia

14/04/2011. "Penjamin utang Bintuni Dipailitkan"

Detik

26/02/2015. Demo Ribuan Nelayan di Depan KKP Lumpuhkan Jalan Medan Merdeka Timur. 03/03/ 2015. Demo Ribuan Nelayan di Batang Rusuh, Lalin Pantura Sempat Lumpuh. 04/03/2015. Demo Rusuh di Batang, 5 Nelayan Ditetapkan Jadi Tersangka. 
18/05/2017. Nelayan Rembang Mengaku Alat Cantrang Tak Rusak Ekosistem Laut.

11/07/2017a. Nelayan Cantrang Minta ke Jokowi Bisa Melaut hingga Desember.

11/07/2017b. Protes Larangan Cantrang, Nelayan Bakar Pocong di Depan Istana.

18/01/2018. Kapal Cantrang Boleh Melaut Lagi, Ini Syarat dari Susi.

Kompas

26/06/1969, "Sistim Trawl Dalam Usaha Modernisasi Penangkapan Ikan".

15/10/1977, "Sekitar Kapal Trawl yang Diserbu Nelayan".

18/10/1979, "Kapal Pukat Harimau Masih Beroperasi 6 Mil dari Pantai”. 27/05/1980. Masalah Trawl di Indonesia

05/01/1980, "Posisi Pukat Harimau Strategis di Sektor Penyediaan Ikan Asin".

05/04/1980, "Pernyataan HNSI. Sebaiknya Pukat Harimau Dihapus". 16/05/1980, "Presiden Setujui Usul HNSI".

09/09/1980a, "Kita Siap menanggulangi Akibat Penghapusan Trawl".

09/09/1980b, "Kredit Untuk Nelayan Jateng Belum Diberikan akibat Perbedaan Pendapat".

24/09/1980, "Melihat Latihan Ketrampilan Nelayan Eks Kapal Trawl Jabar".

10/10/1980, "Pengasin Ikan Jakarta Terpukul".

07/11/1980, "Dimulai, Latihan Ketrampilan ABK Bekas Trawl di Jawa Timur".

31/12/1982, "Penghapusan Trawl Belum Selesaikan Masalah Inti Nelayan".

27/03/1982, "Nelayan Trawl Membuka Tambak Udang".

03/01/1983, "Riwayat Pukat Harimau Berakhir".

13/12/1984, "Pukat Harimau Masih beroperasi di Selat Laut".

18/05/1985, "Pukat Harimau Masih beroperasi".

20/06/1994, "Nelayan Pantai Cirebon Gunakan Jaring Arad".

02/01/1996, "Jaring Arad Dilarang, Ribuan Nelayan di Pantura Menganggur".

04/03/2015, "Nelayan Batang Blokade Jalan Pantura".

23/02/2015, "Tolak Larangan "Trawl” Mini".

19/06/2015, "Pengalihan Alat Cantrang Dimulai".

13/11/2016, "Kapal Vietnam Ditangkap".

De Locomotief

24/05/1933 "Noordkust".

19/06/1936 "Vischaanvoer".
Het Nieuws van den dag voor Nederlandsch-Indië n.d. 28/10/1925 "Hoe het Volkscredietwezen werkt".

Radar Pekalongan

23/12/2017. "Hasil Uji Petik. Cantrang Tidak Masuk Kategori Alat Tidak ramah Lingkungan".

Suara Merdeka

17/09/2017. "Karding: Pemerintah Jangan Sekadar Larang Cantrang, Tetapi Diimbangi dengan Solusi".

02/10/2017. "DPR Dorong Uji Petik Pelarangan Cantrang".

13/10/2017. "Nelayan Tawarkan Uji Petik Cantrang".

15/11/2017. "Susi Prihatin Nelayan Masih Ributkan Cantrang".

23/12/2017. "Komunitas Perikanan Batang Minta Larangan Penggunaan Cantrang Dicabut".

09/01/2018. "DPRD Desak Pemerintah Evaluasi Pelarangan Cantrang". 31/03/2018. "Nelayan Klaim Cantrang Ramah Lingkungan".

28/04/2018. "Ida Fauziyah Janji Perjuangkan Legalitas Cantrang".

08/01/2019. "Terkendela Biaya, Ratusan Cantrang Masih Bertahan".

\section{GoI (Government of Indonesia)}

Law No 1/1967 on Foreign Investment.

Law No 6/1968 on Domestic Investment.

Presidential Decree. No 39/1980 on the Trawler Ban.

Presidential Decree. No. 40/1997 on the Mass Agricultural Extension Program.

Minister of Marine Affairs and Fisheries Decree No. 509/1996 on Import of Trawler Boats.

Minister of Marine Affairs and Fisheries Decree No. 6/2010 on Fishing Gears in Indonesian Fishing Territory.

Minister of Marine Affairs and Fisheries Decree No. 2/2015 on Prohibition of Trawl and Seine nets.

Minister of Marine Affairs and Fisheries Circular Letter No.72/MEN-KP/ II/2016 on Restriction on the Use of Cantrang Seine in Indonesian Fishing Territory.

Minister of Marine Affairs and Fisheries Circular letter B.1/SJ/PL.610/I/ 2017 on Replacement of Prohibited Fishing Gears in Indonesian Fishing Territory.

Publisher's note Springer Nature remains neutral with regard to jurisdictional claims in published maps and institutional affiliations. 